\title{
L. 4.466
}

DOE/JPL/954853-2

ARRAY AUTOMATED ASSEMBLY: PHASE 2

Quarterly Report

By

William E. Taylor

William Kimberly

Nick Mardesich

Angel Pepe

May 1978

Work Performed Under Contract No. NAS-7-100-954853

Spectrolab, Inc.

Sylmar, California
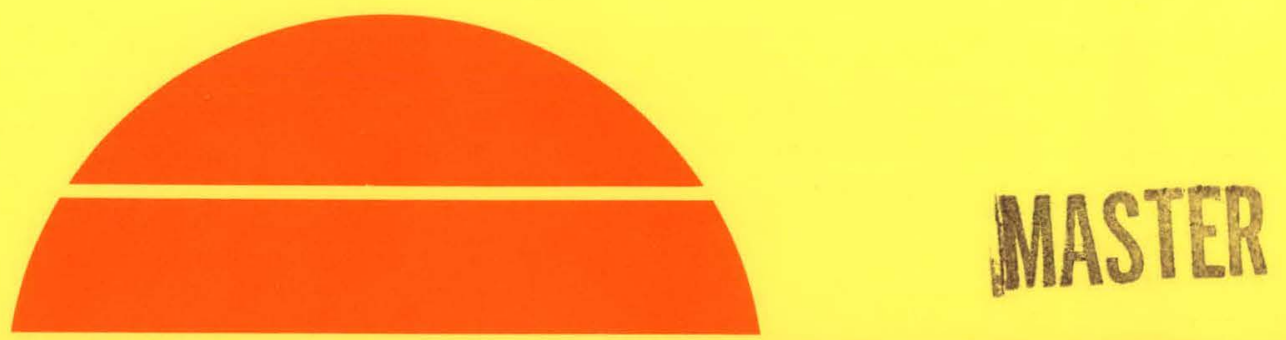

\section{U.S. Department of Energy}




\section{DISCLAIMER}

This report was prepared as an account of work sponsored by an agency of the United States Government. Neither the United States Government nor any agency Thereof, nor any of their employees, makes any warranty, express or implied, or assumes any legal liability or responsibility for the accuracy, completeness, or usefulness of any information, apparatus, product, or process disclosed, or represents that its use would not infringe privately owned rights. Reference herein to any specific commercial product, process, or service by trade name, trademark, manufacturer, or otherwise does not necessarily constitute or imply its endorsement, recommendation, or favoring by the United States Government or any agency thereof. The views and opinions of authors expressed herein do not necessarily state or reflect those of the United States Government or any agency thereof. 


\section{DISCLAIMER}

Portions of this document may be illegible in electronic image products. Images are produced from the best available original document. 


\section{NOTICE}

This report was prepared as an account of work sponsoied by the United Statcs Government. Neither the United States nor the United States Department of Energy, nor any of their employees. nor any nf their contraotoro, subcontiacluis, ur their employees, makes any warranty, express or implied, or assumes any legal liability or responsibility for the accuracy, completeness or usefulness of any information, apparatus, product or process disclosed, or represents that its use would not infringe privately owned rights.

This report has been reproduced directly from the best available copy.

Available from the National Technical Information Service, U. S. Department of Commerce, Springfield, Virginia 22161.

Price: Paper Copy $\$ 5.25$

Microfiche $\$ 3.00$ 


\title{
ARRAY AUTOMATED ASSEMBLY
}

PHASE 2

Quarterly Report

This report was prepared as

sponsored by the United States an account of work

United States nor the Utates Govemment. Neither the

Energy, not any of their lem States Department of

contractors, subcontractors, or thees, nor any of their

any wrrranty, express or or their employees, makes

liability or responsibility for the or assumes any legal

or usefulness of any for the accuracy, completeness

process disclosed, or represents that its us, product or

infringe privately owned rights.
that its use would nnt

William E. Taylor, William Kimberly, Nick Mardesich, and Angel Pepe

\author{
May 1978 \\ JPL Contract No. 954853 \\ SPECTROLAB, INC. \\ 12500 Gladstone Avenue \\ Sylmar, California 91342
}

The JPL Low-Cost Silicon Solar Array Project is sponsored by the U. S. Department of Energy and forms part of the Solar photovoltaic Conversion Program to initiate a major effort toward the development of low-cost solar arrays. This work was performed for the Jet Propulsion Laboratory, California Institute of Technology by agreement between NASA and DoE. 


\section{ABSTRACT}

Surface topography of texturized solar cells was investigated. No significant differences were found between high output and low output cells with a common texturizing treatment. Differences were found between high output and low output cells with a common texturizing treatment. Differences were found associated with variation in the damage removal etch prior to texturizing.

Titania precipitated glasses were found to have suitable properties for use as a diffusion masking dielectric. Preliminary attempts to make solar cells were not successful.

Emulsitone N-250 phosphorous diffusion source was identified to be suitable for solar cell fabrication, and a diffusion procedure was identified.

A number of commercially available fritted silver pastes have been identified as giving promising results. Methods of paste modification by additions of donar source additions and frit content adjustments were found to be effective in proving the performance of some commercial pastes.

Printed silver solder pads on aluminum back contacts were found to be subject to corrosive failure in humidity testing. Tin pads were found to be free of this deficiency.

A module design comprised of an array of 10 by 20 square cells in an area approximately 2 feet by 4 feet was resolved. Projected module efficiency is $12.5 \%$. "LO IRON" sheet glass furnished by ASG Industries was selected for the superstrate as being the most cost effective for projected module costs below $\$ 1.09$ per watt. 
TABLE OF CONTENTS

PAGE

Abstract . . . . . . . . . . . . . . . . . . . . . . $i i$

1.0 SUMMARY . . . . . . . . . . . . . . . . . . . . . 1

2.0 INTRODUCTION. . . . . . . . . . . . . . . . . . 2

2.1 TECHNICAL OVERVIEW OF CELL DESIGN AND PROCESS

SEQUENCE • • • • : • • • • • • • • • • . • • • . 2

\begin{tabular}{l}
2.2 TECHNICAL OVERVIEW OF MODULE DESIGN AND PROCESS \\
SEQUENCE... \\
\hline
\end{tabular}

3.0 TECHNICAL DISCUSSION. . . . . . . . . . . . . . . 10

3.1 SURFACE PREPARATION . . . . . . . . . . . . . . . . . 10

3.2 JUNCTION FORMATION. . . . . . . . . . . . . . . . 13

3.2.1 Diffusion Masking Dielectric . . . . . . . . 13

3.2.2 P+ Back Contact. . . . . . . . . . . . 30

3.2.3 Diffusion. . . . . . . . . . . . . . 33

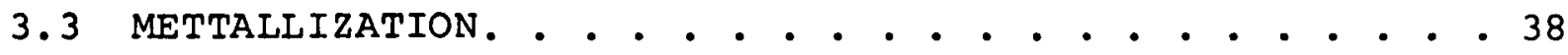

3.3.1 Front Contacts . . . . . . . . . . . 38

3.3.2 Solder Pads. . . . . . . . . . . . 38

3. 4 MODULE ASSEMBLY . . . . . . . . . . . . . . . . . . . . 45

3.4.1 Bonding and Back Coating Materials . . . . . . 45

3.4.2 Glass Evaluation .............. . . 49

3.4.3 Module Design. . . . . . . . . . . . . . 50

4.0 CONCLUSIONS . . . . . . . . . . . . . . . . . . . . . 55

5.0 RECOMMENDATIONS . . . . . . . . . . . . . . . . 57

6.0 NEW TECHNOLOGY. . . . . . . . . . . . . . . . . . . . . . 57

7.0 REFERENCES. . . . . . . . . . . . . . . . . . . . 58 


\subsection{SUMMARY}

Surface topography of texturized solar cells was investigated. No significant differences were found between high output and low output cells with a common texturizing treatment. Differences were found associated with variation in the damage removal etch prior to texturizing.

Titania precipitated glasses were found to have suitable properties for use as a diffusion masking dielectric. Preliminary attempt.s to make solar cells were not successful.

Emulsitone $\mathrm{N}-250$ phosphorous diffusion source was identified to be suitable for solar cell fabrication, and a diffusion procedure was identified.

A number of commercially available fritted silver pastes have. been idenified as giving promising results. Methods of paste modification by additions of donar source additions and frit content adjustment were found to be effective in improving the performance of some commercial pastes.

Printed silver solder pads on aluminum back contacts were found to be subject to corrosive failure in humidity testing. Tin pads were found to be free of this deficiency.

A module design comprised of an array of 10 by 20 square cells in an area approximately 2 feet by 4 feet was resolved on. Projected module efficiency is 12.5\%. "LO IRON" sheet glass furnished by ASG Industries was selected for the superstrate as being the most cost effective for projected module costs below $\$ 1.09$ per watt. 


\subsection{INTRODUCTION}

This is the second quarterly report for an investigation of technology readiness of a proposed process sequence for the low cost fabrication of photovoltaic modules as a part of Phase 2 of the Array Automated Assembly Task, Low Cost Silicon Solar Array Project. It covers the Quarter ending March 31 , 1978 .

2.1 TECHNICAL OVERVIEW OF CELL DESIGN AND PROCESS

The cell design and proposed process sequence are outlined in Table 2-1. Discussion of the module design and process sequence is presented in a subsequent section.

The design included shaped cells in order to achieve the goal of 12-13\% module efficiency. During the first quarter an analysis of cost trade-offs showed that the optimum degree of partial shaping from cylindrical crystals would be a circle with small flats, leading to significant unoccupied interstitial areas in the module. We have resolved to use square cells shaped from Czochralski crystals for process verification purposes in anticipation of the eventual availability of square or rectangular sheet material.

Spectrolab's plan includes the use of texturized surfaces, conforming with the conclusions of the Phase 1 studies that this is advantageous. Texturizing is already well developed for (100) oriented single crystal material. During the first quarter it was found that a single step texturizing process is adequate, under some circumstances, to also remove saw damaged surface material. 
Table 2-1

CELL DESIGN AND PROCESS SEQUENCE

AS PROPOSED

1. Design:

Shaped, size $25-100 \mathrm{~cm}^{2}\left(4-16 \mathrm{in}^{2}\right)$

Texturized surface

$n+$ junction diffusion

pt back surface field

printed contact metallization

Wraparound contacts

$n_{C}=158\left(28^{\circ} \mathrm{C}, 100 \mathrm{~mW} / \mathrm{cm}^{2}\right)$

2. Process Sequence:

1) Surface Preparation

2) Print edge masking dielectric

3) Fire edge masking dielectric

4) Print back aluminum

5) Apply front polymer dopant

6) Fire junction and back surface field sources

7) Print back isolation dielectric

8) Fire back isolation dielectric

9) Print contact pads

10) Print front grid pattern and wraparound conductors

11) Fire contact pads, grid pattern and wraparound conductors

12) Test cells 
The cell design included a p+ back field obtained from a printed aluminum source. The nt diffusion was to be obtained from a phosphorus doped polymer source. An innovative approach to the junction formation process was included: namely, the use of a prefired masking dielectric on the edge of the cell. This was intended to permit the codiffusion of the $\mathrm{n}+$ and $\mathrm{p}+$ regions without the need for an edge etch. As a further innovation, it was proposed that the diffusion oxide not be removed, but be retained to serve as an antireflection coating. During the first quarter cofiring of the aluminum hark fiel. during diffusion wae found to be unsatisfactory. However it was observed that the printed aluminum can be fired through a diffused layer with satisfactory results. This will permit the use of a separate firing step without back etching provided a suitable diffusion mask can be developed.

During the first quarter four glass systems were selected for detailed consideration as edge masking dielectrics. These were

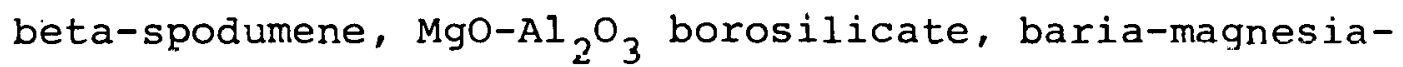
borosilicate and titania precipitated glasses. During the present (second quarter) it was decided to locate the diffusion mask in a narrow band around the outside perimeter of the back surface rather than on the edge of the cell. The $\mathrm{MgO}^{-\mathrm{Al}_{2} \mathrm{O}_{3}}$ borosilicate glass series was eliminated and a revised version of the baria-magnesia-borosilicate glass introduced. The titania glass formulation has been tested with positive results as to a diffusion barrier; however, attenpts to integrate this process into the total process sequence have not been satisfactory.

A spin-on diffusion source, Emulsitone $\mathrm{N}-250$ has been selected. Sprayon and contact transfer application techniques are being evaluated. During the present quarter it has been determined that retention of the diffusion oxide results in excess series 
resistance, and hence its retention as an AR coating is not feasible. However it has been found that under some conditions removel of the diffusion oxide leaves a residual stain which may be suitable for an AR coating.

A further use for the edge masking dielectric was to be as an insulation layer for wraparound contacts. Relocation of the diffusion mask to the back surface eliminates the need for an insulation layer on the cell edge, since the diffused layer will now extend down over the edge. The diffusion mask will continue to serve as an isolation dielectric in its new location.

At this point an additional printing and firing operation was introduced to locate dielectric insolation pads for the wraparound contacts on the back aluminum. This was followed by printing solderable contacting pads on the back surface. During the present quarter silver contact pads on the aluminum back have been found to be unsuitable because of galvanic corrosion effects. Tin applied by ultrasonic soldering techniques has been found to be more satisfactory. The front metallization grids and wraparound conductiors are then printed. For this we proposed using an aluminum thick film paste. Finally, the front contact grids and solderable contacts on the back side would be cofired to complete the cell fabrication. During the first quarter difficulties were encountered with aluminum front contact paste. It was decided to concentrate on developing a screen printed silver paste front contact process. Substantial progress has been made during the second quarter in understanding and improving the performance of screen printed silver front contacts.

The cell design and process sequence as modified by work performed during the first and second quarters is shown in Table 2-2. 
Table 2-2

\section{CELI DESIGN AND PROCESS SEQUENCE}

Revised April 1, 1978

1. Design:

Shaped, size $5.38 \mathrm{~cm}$ square $\left(29 \mathrm{~cm}^{2}\right)$

Tcxturized surface

$\mathrm{n}+$ junction diffusion

p+ bask surfare field

Printed contact metallization

Wraparound contacts

$n_{c}=158\left(28^{0} \mathrm{C}, 100 \mathrm{mw} / \mathrm{cm}^{2}\right)$

2. Process Sequence:

1) Texture Etch

2) Print edge masking dielectric

3) Fire edge masking dielectric

4) Apply front polymer dopant

5) Diffusion

6) Print aluminum back

6a) Fire aluminum back

7) Print back isolation dielectric

8) Fire back isolation dielectric

9). Print contact pad over dielectric

10) Print front grid pattern and wraparound conductors

11) Fire contact pad, grid pattern and wraparound conductors

1.1.a) Apply tin solder pad on aluminum back

12) Test cells 
The module design and selected process sequence are shown in Table 2-3. The module design was comprised of a 24 by 48 inch $(60 \times 120 \mathrm{~cm})$ tempered glass superstrate. Square shaped cells were to be used in order to achieve $12 \%$ module efficiency goal. During the present quarter, square cells based on 3 inch diameter czochralski crystals have been decided on as test vehicles for process verification in anticipation of larger square or rectangular sheet materials becoming available. The crystals will be shaped into prisms with square cross section prior to sawing wafers. The nominal wafer dimension will be $5.38 \mathrm{~cm}(2.12$ inches) on the side. A tentative module design has been prepared comprised of a $10 \times 20$ cell layout. Cells will be interconnected into a circuit with ten cells in parallel and twenty cells in series. The module is expected to have a peak power of 84 watts at $28^{\circ} \mathrm{C}$ and 9.4 volts.

The module structure uses a thin bond line adhesive to attach the solar cells to the glass superstrate. Since silicone adhesives were known to be technically feasible, and the thin bond line minimizes costs, they were included in the original design. However, alternative adhesives were to be evaluated in a search for greatcr cost effectiveness. A large number of adhesive candidates has been evaluated, and a final selection has not yet been made. Silicone adhesives are, however, still leading contenders. Interconnect conductors were to be in the form of thin copper foil mounted on a plastic film. The copper foil would be stamp-cut to preform the interconnects after mounting on the carrier film. A simple automatic reflow soldering operation is permitted by the wraparound techniques used to position both contacts on the back sides of the cells. After 
Table 2-3

MODULE DESIGN AND PROCESS SEQUENCE

1. Desj.gn

Size $60 \times 120 \mathrm{~cm}(2 \times 4 \mathrm{ft})$

Tempered glass superstrate

Cells attached by polymeric adhesive

Preformed circuit interconnects

3 mil. polymeric contormal coating

Aluminum extrusion frame

$n_{m}=138$

2. Process Sequence*

13. AR Treat Superstrate Glass

14. Mount cells on Superstrate

1.5. Cure Adhesive

16. Apply Interconnerts

17. Apply Conformal coat

18. Cure Conformal Coat

19. Mount in Frame

20. Test Module

* Process sequence numbers continue from the cell area (Table 2-1) 
soldering, the carrier film and excess copper foil would be recycled. This scheme has been abandoned because of the costs of recycling the large fraction of material not actually used for interconnects on any one module. Spool fed thin ribbons can be used with equal facility and without generating large amounts of recyclable scrap. The use of flat woven mesh or braid is still under consideration as an alternative material.

A silicone conformal coating was proposed as the encapsulant and rear surface, the module assembly to be completed by mounting the superstrate in an aluminum extrusion frame. A number of coating material candidates have been considered during the first and second contract quarters. Silicone is still a leading candidate, however acrylic and polyurethane candidates have been added for evaluation as possibly being more cost effective. Preliminary designs of the extrusion shapes for the frame have been completed. 


\subsection{TECHNICAL DISCUSSION}

\subsection{SURFACE PREPARATION}

The texturing of silicon wafers provides an antireflective surface as well as a method of removing damage due to slicing. During this quarter, surface topography was investigated with a Scanning Electron Microscope to distinguish between surfaces generated with the use of a pre-etch to remove surface damaqe and those produced by direct texture etching of slurry-sawed wafers. Surfaces examined were on cells qenerated in the previous quarter to study the effect of eliminating the pre-etrh (1). Cells were selected for examination to include a high output and a low output cell from three surface treatment groups. The cells, their treatment and elcctrical parameters are identified in Table 3-1.

All three groups had been etched and/or texturized with solutions of $\mathrm{NaOH}$. A hot, aqueous $30 \% \mathrm{NaOH}$ solution etches the surface lairly uniformly, but leaves pits about $50 \mu \mathrm{m}$ in diameter. A hot $2 \% \mathrm{NaOH}, 20 \%$ Isopropyl Alcohol, texturing solution has a negligible etch rate in the (1,11) direction which leaves llie (100) surface with four sided pyramids. The rate at which these $\mathrm{NaOH}$ solutions attack the surface is dependent on the amount of surface damage, the temperature of the solution, the solution concentration, the relative frcewbond deusity and the solute molecule diffusion through the reaction boundary layer.

The first pair of cells was prepared by slurry-fed ganged slicing followed by cleaning and texture etching with $2 \%$ alcoholic $\mathrm{NaOH}$ at $80^{\circ} \mathrm{C}$ for. 55 minutes. Figures $\mathrm{la}$ and $1 \mathrm{~b}$ show a typical surface region of the higher output solar cell; the surface appears to be free of pitting. The pyramids are broad and have a distribution ranging from 0.2 to 
Table 3-1

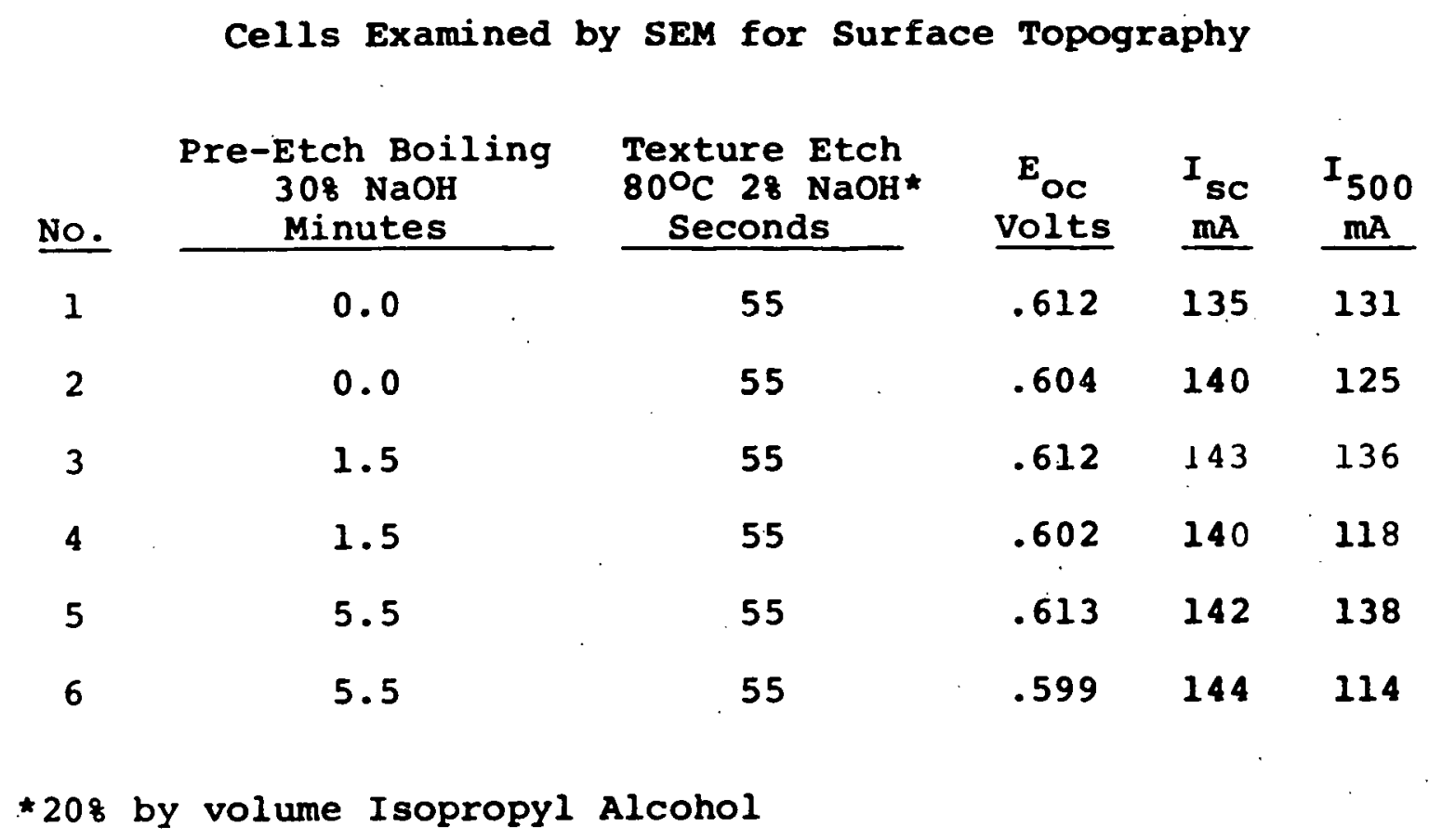


to $15 \mu \mathrm{m}$ with the two extremes disproportionately represented. An average surface section of the lower output solar cell has pits of about $50 \mu \mathrm{m}$ in diameter, (Figure 2a) and has a slightly higher density of small pyramids (Figure $2 b$ ).

The second pair of cells was prepared in a manner sililar to Group I but had a $308 \mathrm{NaOH}$ etching treatment at $110^{\circ} \mathrm{C}$ for 1.5 minutes prior to the texturing treatment. The high output device has pits of 30 to $60 \mu \mathrm{m}$ (Figure 3a). Small pyramids of about $4 \mathrm{\mu m}$ in base width diameter and a narrow size distribution appear on the surface (Figure $3 b$ ). There seems to be a larger number of deeper pits of the same diameter in the low output solar cell (Figure $4 \mathrm{a}$ ). The pyramid morphology and density seems to be about the same as that of the high output solar cell (figure $4 \mathrm{a}$ ).

The third pair of cells had a 5.5 minute $30 \% \mathrm{NaOH}$ etching treatment prior to texturing. An average surface section of the high output solar cell has very deep $25 \mu \mathrm{m}$ pits (Figure 5a). The pyramids appear very thin with most of the base diameters being either large $\hat{\imath} 12 \mu \mathrm{m}$ or small $\approx 4 \mu \mathrm{m}$ (Figure 5b). The low output cell does not have many pits (Figure 6a), but does have the same thin shaped pyramids (Figure 6b).

The best solar cells appeared to have minimal pitting with large broad pyramids, height to base diameter ratio of about 0.5 to 1.0 . However there does not appear to be a significant difference in the observable surface structure of high and low output cells. Differences in etch treatment lead to differences in observable structure which may be significant in terms of cell output. The overall yield of high output solar cells was degraded as more pretexturing treatment occurred. (1) The yield progressed: Group $1>$ Group $2>$ Group 3. The small thin pyramids observed with long pre-etch times may be more susceptible to mechanical damage during the fabrication of the cell, thus resulting in more recombination centers or shunting and poor yield. It must be noted that only one sample of each group was examined microscopically. 


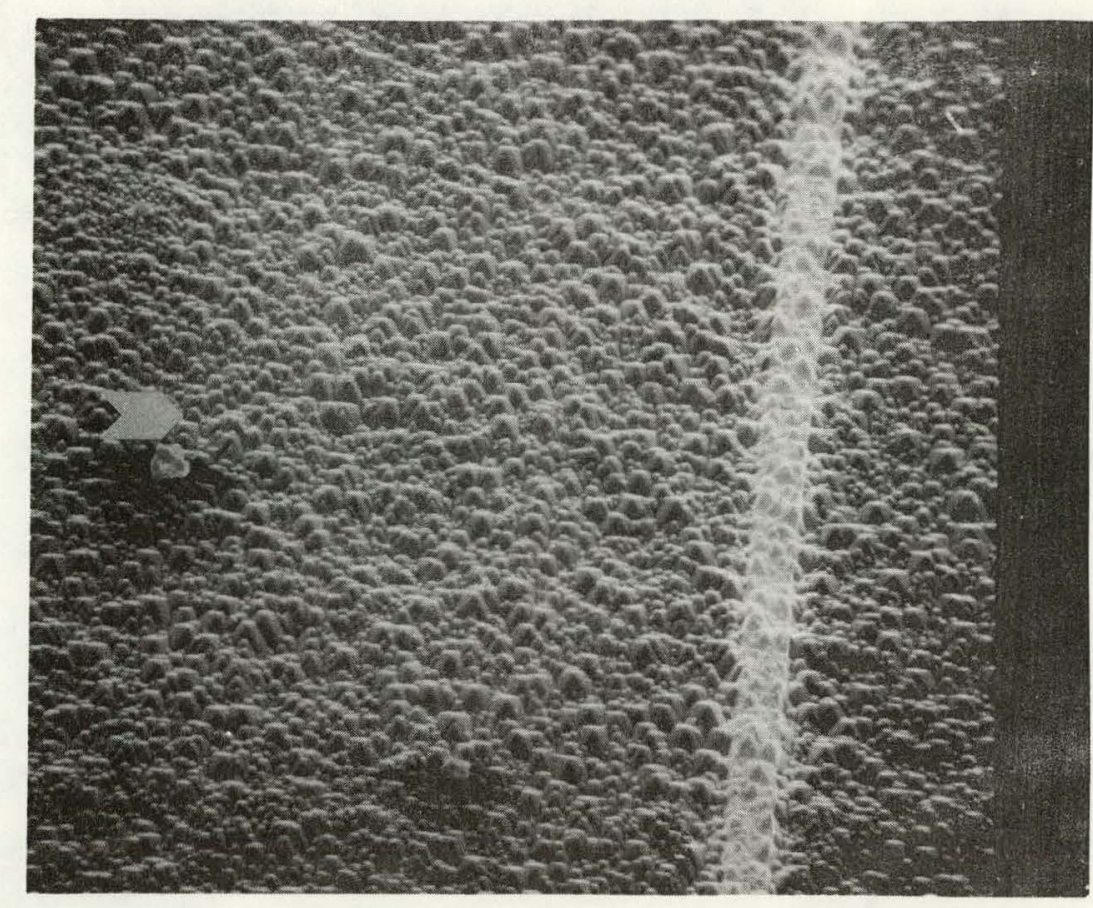

Figure la. $200 \mathrm{x}$

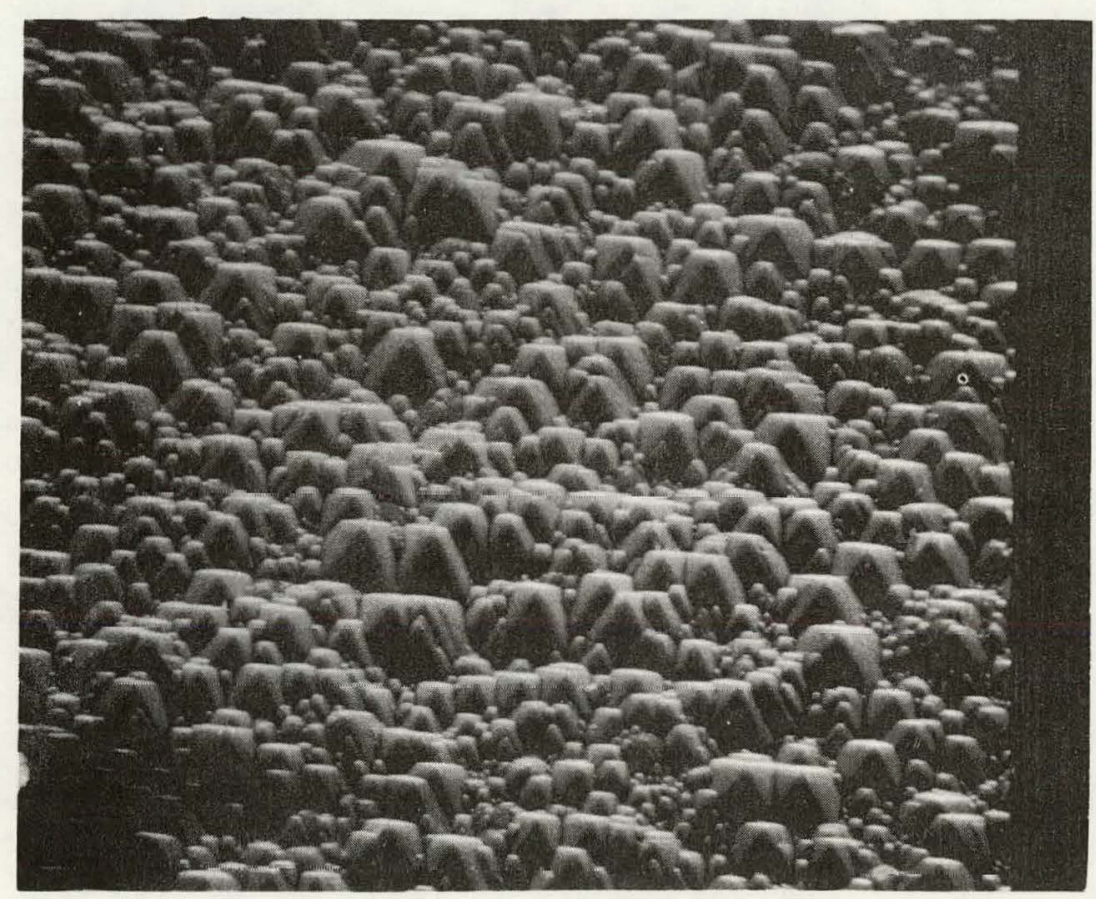

Figure 1 .

$500 x$

Figure 1. Surface Topography of High Output Solar Cell Prepared by 'l'exture Etching with No Prior Damage Removed 


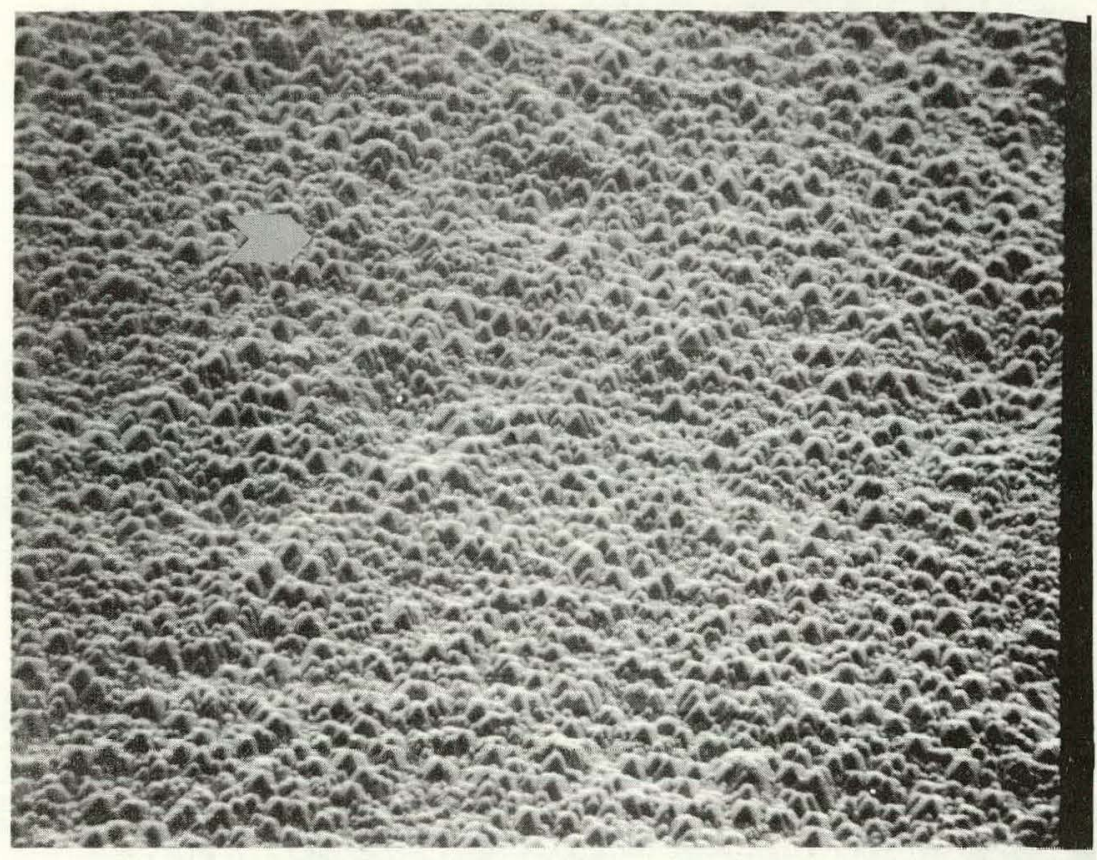

Figure 2a. $200 x$

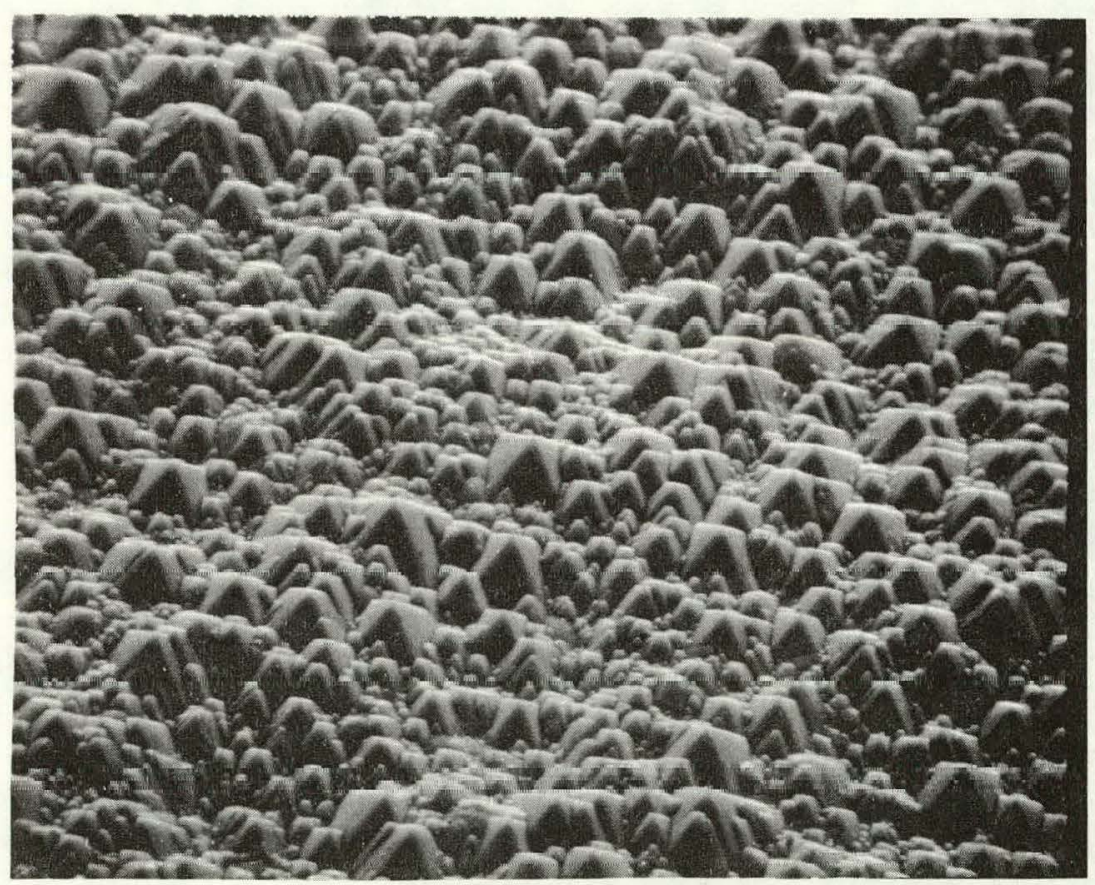

Figure 2b. $\quad 500 \mathrm{x}$

Figure 2. Surface Topography of Low Output Solar Cell Prepared by Texture Etching with No Prior Damage Removed 


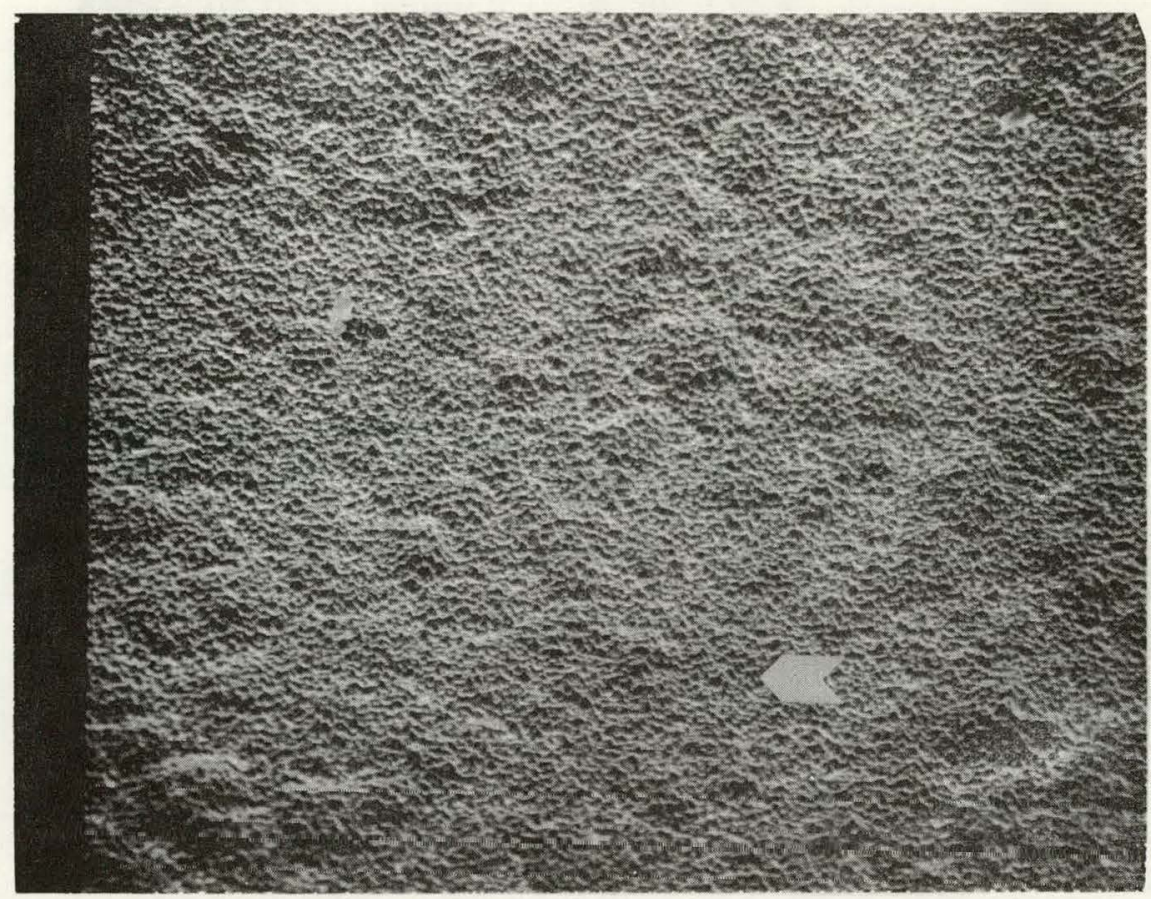

Figure $3 a$. $200 x$

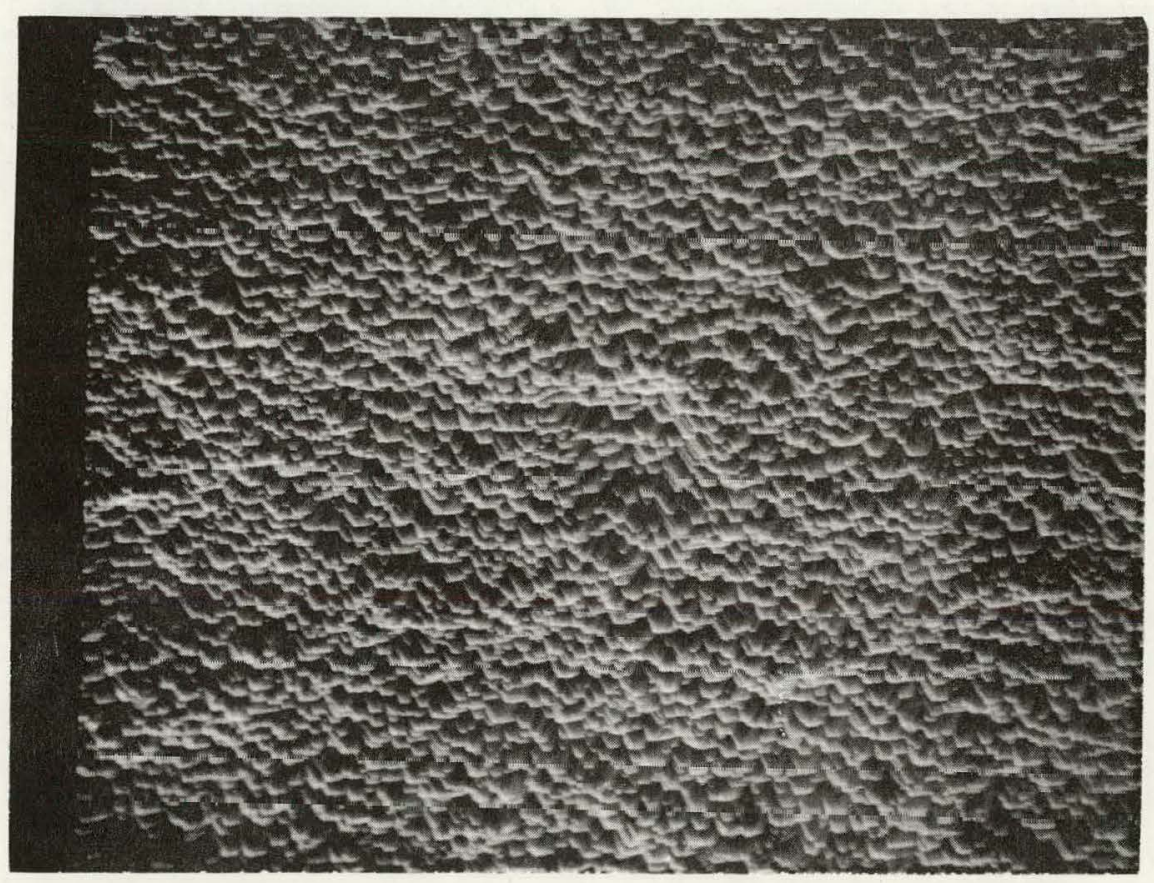

Figure 3b. $\quad 500 x$

Figure 3. Surface Topography of High Output Solar Cell Prepared by Texture Etch After 1.5 Minutes in $30 \% \mathrm{NaOH}$ Solution at $110^{\circ} \mathrm{C}$ 


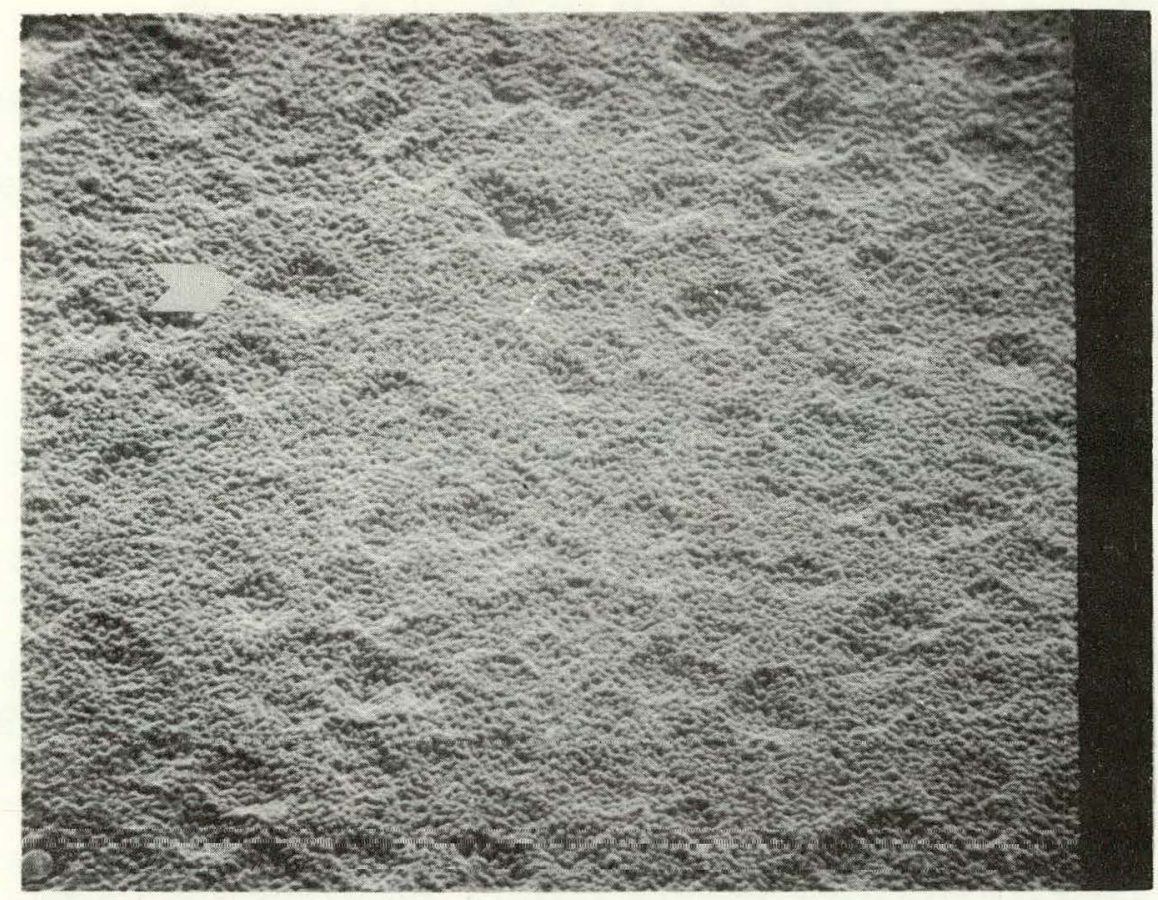

Figure 4 a. $\quad 200 x$

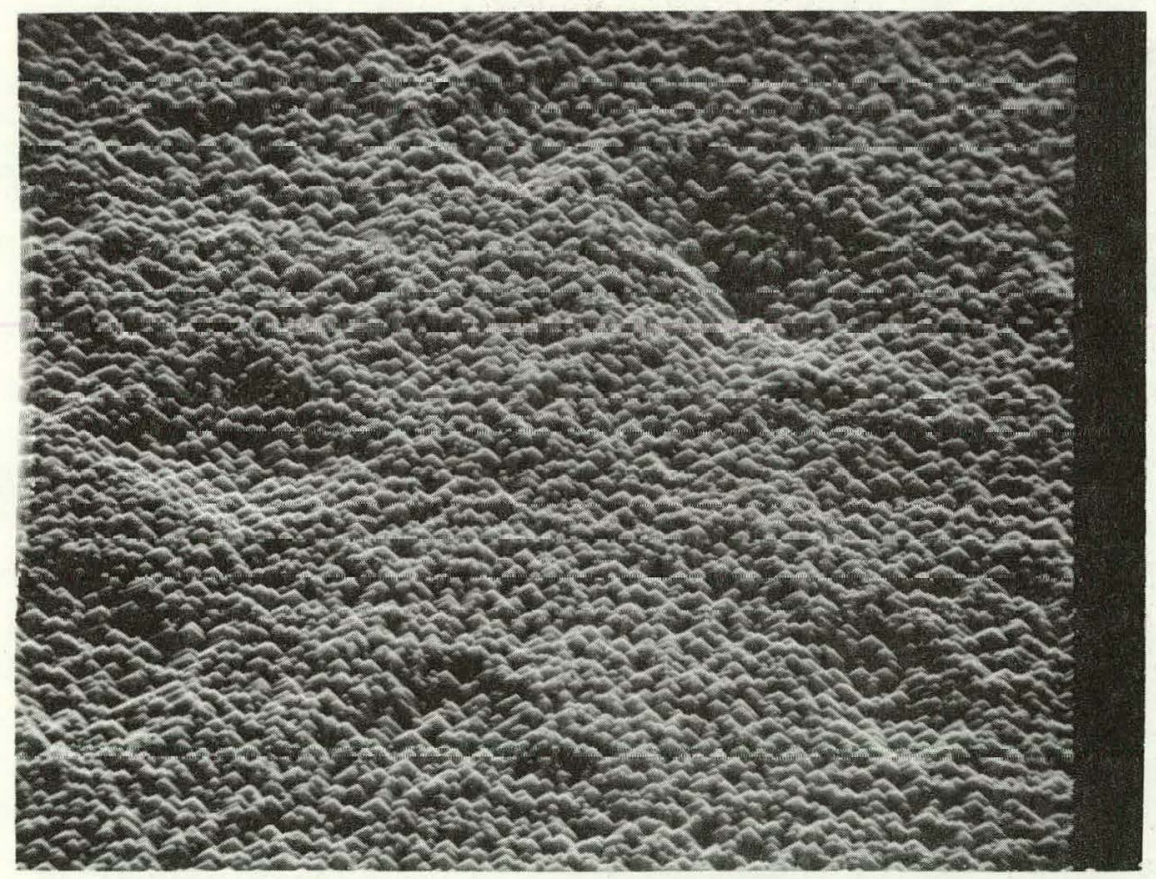

Figure $4 \mathrm{~b}$. $\quad 500 \mathrm{x}$

Figure 4. Surface Topography of Low Output Solar Cells Prepared by Texture Etching After 1.5 Minutes in $30 \% \mathrm{NaOH}$ Solution at $1100^{\circ} \mathrm{C}$ 


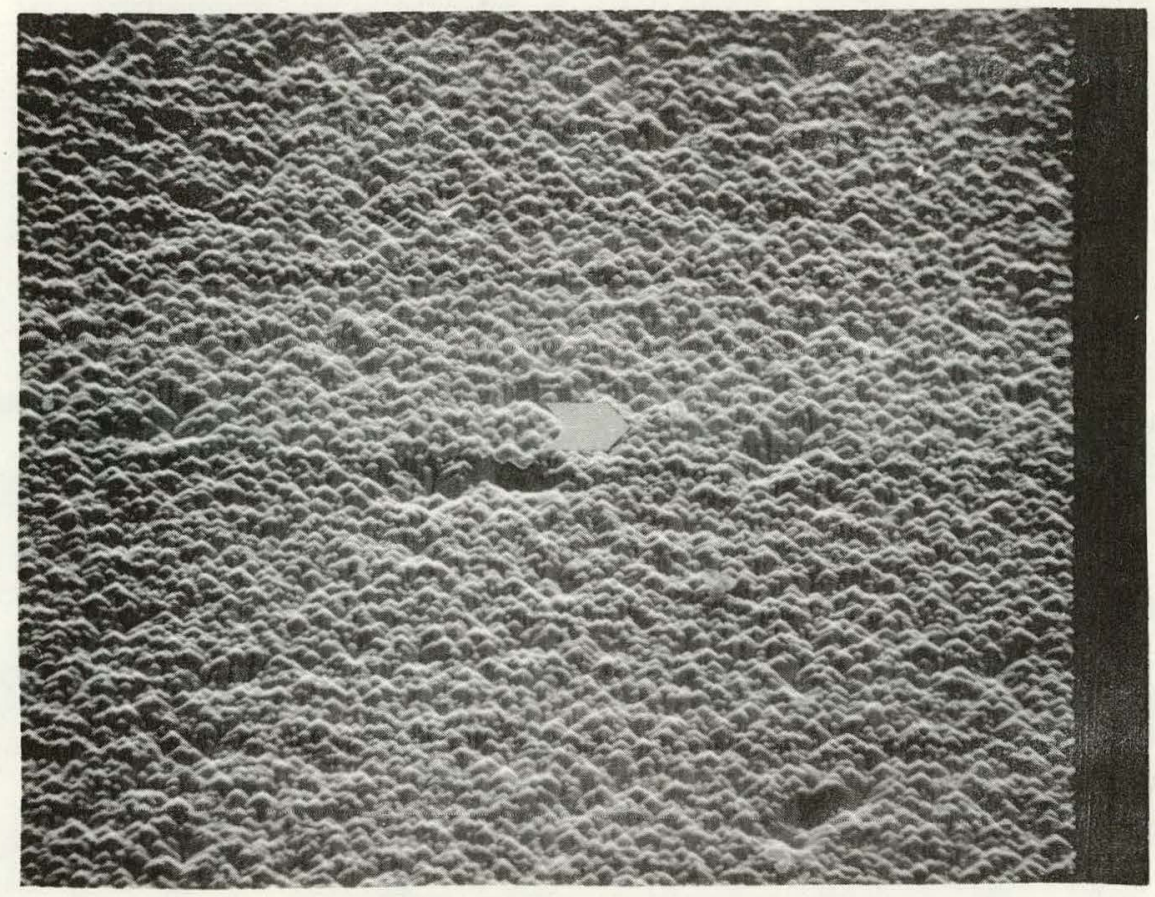

Figure 5a. $200 x$

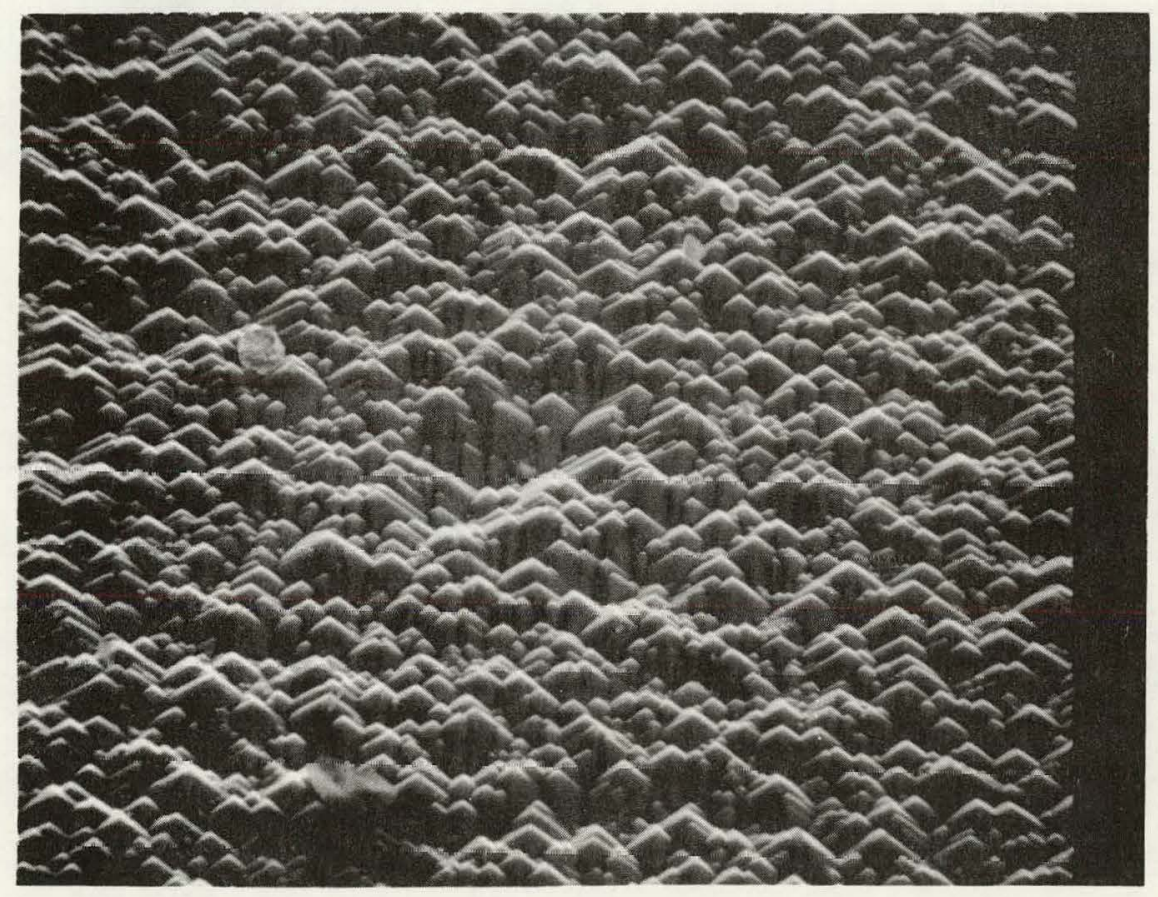

Figure 5b. $\quad 500 \mathrm{x}$

Figure 5. Surface Topography of High Output Solar Cell Prepared by Texture Etching After 5.5 Minutes in $30 \% \mathrm{NaOH}$ solution at $110^{\circ} \mathrm{C}$ 


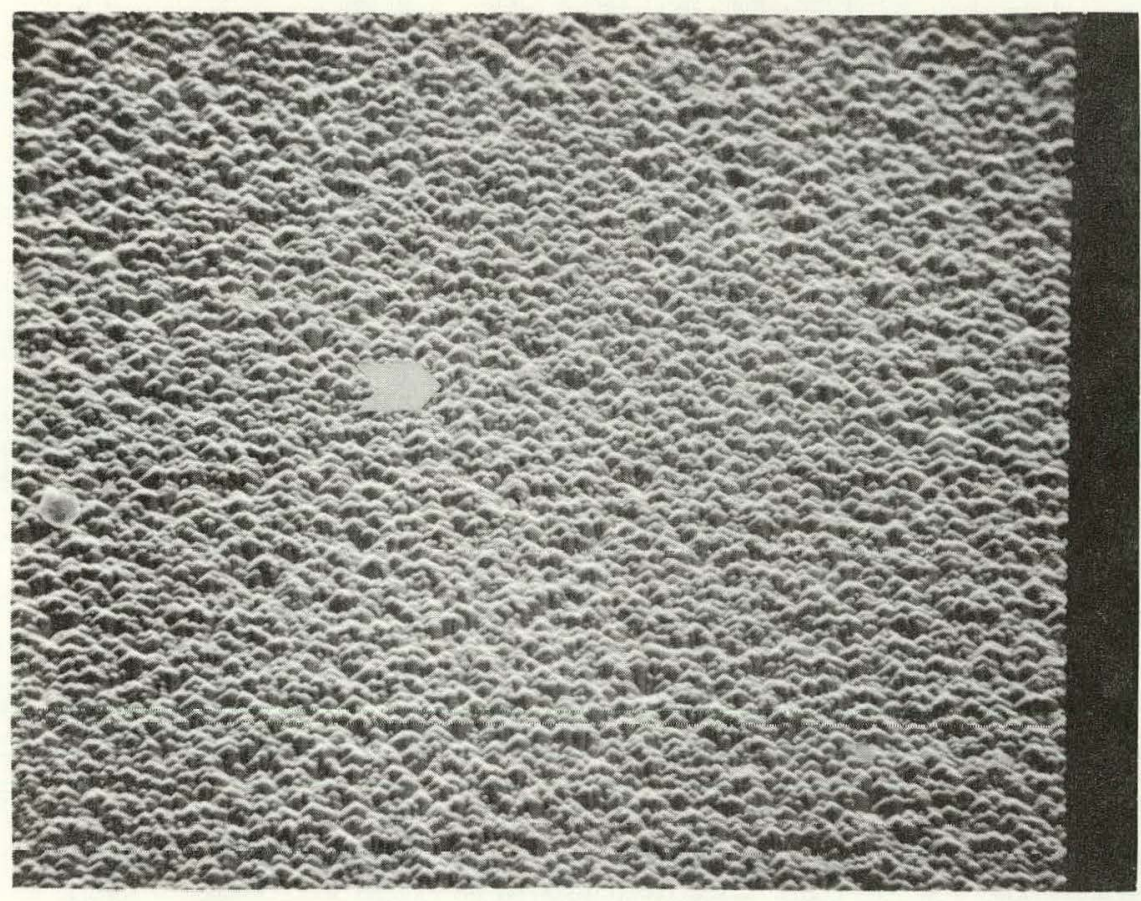

Figure 6a. $200 x$

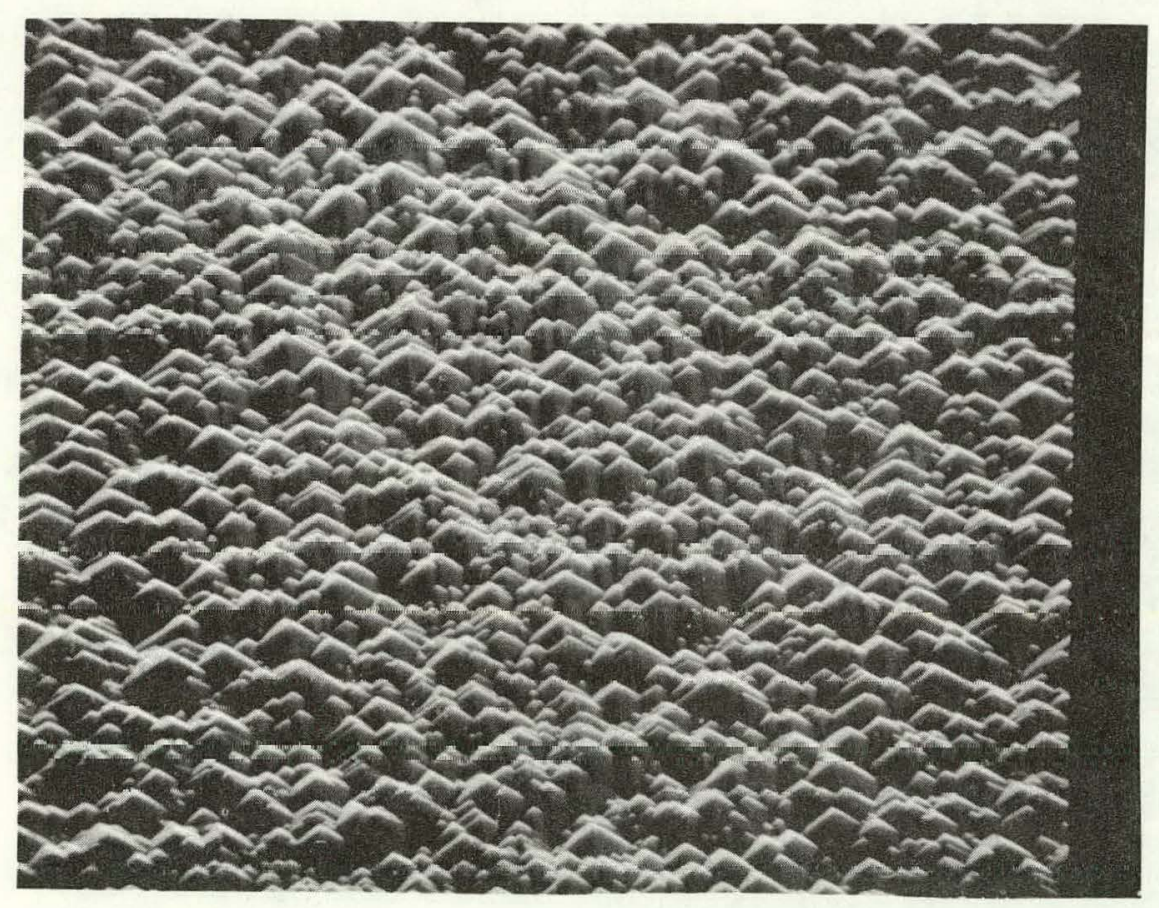

Figure 6b. $\quad 500 x$

Figure 6. Surface Topography of Low Output Solar Cell Prepared by Texture Etching After 5.5 Minutes in $30 \% \mathrm{NaOH}$ at $1100 \mathrm{C}$ 


\subsubsection{Diffusion Masking Dielectric}

\section{Glass Formation}

The glasses for this application were selected on the basis of (1) maturation temperature, (2) resistance to phosphorous diffusion, (3) expansion coefficient, (4) thermal stability, and (5) composition. Specific requirements are as follows:

1 - Maturation temperature between 850 and $900^{\circ} \mathrm{C}$

2 - Thermal expansion coefficient between 3.9 and $4.6 \times 10^{-6} /{ }^{\circ} \mathrm{C}$

3 - Capable of being thermal cycled to $850^{\circ} \mathrm{C}$ and $650^{\circ} \mathrm{C}$ without loss of adherence to the silicon or dielectric characteristics

4 - Oxides comprising the coating shall not reduce the power characteristics of the solar cell.

Based on requirements (1), (2), and (3), five families of glasses were selected as potential candidates. The initial compositions are shown in Table $3-2$.

\section{Series 1 - Beta Spodumene Glasses}

This family of glass was selected because of low expansion characteristics and low viscosity at about $1090^{\circ} \mathrm{C}$. Additionally prescription of spodumene promotes thermal stability.

Series 2 - Magnesia-Alumina Borosilicate Glasses

These glasses are based on a composition from the Ferro corporation which has a calculated expansion coefficient of $3.9 \times 10^{-6} /{ }^{\circ} \mathrm{C}$ ' and a maturation temperature of $1010^{\circ} \mathrm{C}$. 
Table 3-2

Starting Compositions of Diffusion Masking

\section{Dielectrics}

Series

Oxide

1

2

3

5

7

Equivalents

\begin{tabular}{|c|c|c|c|c|c|c|}
\hline $\mathrm{BaO}$ & & - & - & 0.133 & - & 0.395 \\
\hline $\mathrm{Ii}_{2} \mathrm{O}$ & & 0.811 & - & - & 0.149 & - \\
\hline Mqo & . & 0.189 & 0.875 & 0.783 & - & 0.436 \\
\hline Can & . & - & 0.125 & 0.043 & 0.080 & 0.085 \\
\hline Zno & & - & - & 0.041 & 0.055 & 0.084 \\
\hline $\mathrm{Na}_{2} \mathrm{O}$ & & - & - & - & 0.505 & - \\
\hline $\mathrm{K}_{2} \mathrm{O}$ & & $=$ & $=$ & $=$ & 0.211 & $=$ \\
\hline Total & & 1.000 & 1.000 & 1.000 & 1.000 & 1.000 \\
\hline $\mathrm{B}_{2} \mathrm{O}_{3}$ & & - & 1.382 & 1.753 & 0.644 & 0.766 \\
\hline $\mathrm{Al}_{2} \mathrm{O}_{3}$ & & 0.282 & 0.330 & - & - & - \\
\hline \multirow[t]{2}{*}{$\mathrm{P}_{2} \mathrm{O}_{5}$} & & 0.340 & - & - & - & - \\
\hline & & - & - & - & - & - \\
\hline $\mathrm{SiO}_{2}$ & & 3.023 & 2.334 & 1.016 & 2.669 & 0.857 \\
\hline $\mathrm{TiO}_{2}$ & & - & - & - & 1.178 & - \\
\hline
\end{tabular}

Mo1 Percent

\begin{tabular}{llllll}
$\mathrm{BaO}$ & - & - & 3.52 & - & 15.06 \\
$\mathrm{Li}_{2} \mathrm{O}$ & 17.46 & - & - & 2.71 & \multicolumn{1}{l}{-} \\
$\mathrm{MgO}$ & 4.07 & 17.34 & 20.79 & - & 16.62 \\
$\mathrm{CaO}$ & - & 2.48 & 1.14 & 1.46 & 3.24 \\
$\mathrm{ZnO}$ & - & - & 1.09 & 1.00 & 3.20 \\
$\mathrm{Na}_{2} \mathrm{O}$ & - & - & - & 9.20 & - \\
$\mathrm{K}_{2} \mathrm{O}^{2}$ & - & - & - & 3.84 & - \\
$\mathrm{B}_{2} \mathrm{O}_{3}$ & - & 27.39 & 46.51 & 11.73 & 29.20 \\
$\mathrm{Al}_{2} \mathrm{O}_{3}$ & 6.07 & 6.54 & - & - & - \\
$\mathrm{P}_{2} \mathrm{O}_{5}$ & 7.32 & - & - & - & - \\
$\mathrm{SiO}_{2}$ & 65.08 & 46.25 & 26.96 & 48.61 & 32.67 \\
$\mathrm{TiO}_{2}$ & - & - & - & 21.45 & -
\end{tabular}


Series 3 - Baria-Magnesia Borosilicate

This series has a maturation temperature of $1000^{\circ} \mathrm{C}$ and a low expansion due to the high content of $\mathrm{MgO}, \mathrm{B}_{2} \mathrm{O}_{3}$ and $\mathrm{SiO}_{2}$. This series is similar to Series 7, although the latter has a higher $\mathrm{BaO}$ and lower $\mathrm{MgO}$, and $\mathrm{B}_{2} \mathrm{O}_{3}$ content.

Series 5 - Titania Precipitated Glass

This glass, when smelted and water quenced (i.e., cooled quickly) is transparent. When it is matured on a substrate and cooled slowly (air-quenched) through $620^{\circ} \mathrm{C}$ and $700^{\circ} \mathrm{C}$ the titania crystallizes as a mixture of anatese and rutile. This structure is a prime contributor to thermal stability of the coating.

Series 7 - Baria Magnesia Borosilicate

These glasses are similar to those in series 3; except that initially they contained a higher quantity of BaO and a lower quantity of $\mathrm{MgO}$ and $\mathrm{SiO}_{2}$. They are therefore "softer" glasses and would tend to have lower maturation temperature than those of series 3 . The Series 7 glasses are lithia and sodium free.

The development of these glasses to meet the requirements stated above are discussed below.

Series 1

The original composition, designated $1 \mathrm{E}-2$, was selected to assure fomation of Beta spodumene, is shown in Table 3-3. This composition did not smelt to a liquid consistency at 1400 to $1500^{\circ} \mathrm{C}$. A decrease in silica, increase of $\mathrm{P}_{2} \mathrm{O}_{5}$ and additions of $\mathrm{Na}_{2} \mathrm{O}$, as shown in composition $1 \mathrm{E}-8$ was required to obtain a smelt which poured readily. The latter composition was applied to silicon and fired for 5 minutes at $800^{\circ} \mathrm{C}$. The coating exhibited excellent maturity, but an extremely'high wetting angle. The composition was altered by reducing the $\mathrm{P}_{2} \mathrm{O}_{5}$ content to 1.000 equivalents 
Table $3-3$

Compositions of $1 \mathrm{E}$ Series

Oxide IE-2 IE-8 IE-11 $1 E-12$ 1E-13 IE-14

Equivalents

\begin{tabular}{|c|c|c|c|c|c|c|}
\hline $\mathrm{Ii}_{2} \mathrm{O}$ & 0.811 & 0.649 & 0.649 & $0.649^{(1)}$ & $0.605^{(3)}$ & $0.664^{(5)}$ \\
\hline $\mathrm{MgO}$ & 0.189 & 0.151 & 0.151 & 0.151 & 0.208 & 0.131 \\
\hline $\mathrm{Na}_{2} \mathrm{O}$ & $=$ & 0.200 & 0.200 & $0.200^{27}$ & $0.187^{(4)}$ & $0.206^{(6)}$ \\
\hline Total & 1.000 & 1.000 & 1.000 & 1.000 & 1.000 & 1.000 \\
\hline $\mathrm{Al}_{2} \mathrm{O}_{3}$ & 0.282 & 0.226 & 0.226 & 0.226 & 0.212 & 0.232 \\
\hline $\mathrm{P}_{2} \mathrm{O}_{5}$ & 0.340 & 1.260 & 1.000 & 1.260 & 1.081 & 1.287 \\
\hline $\mathrm{B}_{2} \mathrm{O}_{3}$ & - & - & 0.250 & - & - & \\
\hline & 3.023 & 0.850 & 0.850 & 0.850 & 0.796 & 0.873 \\
\hline $\mathrm{SnO}_{2}$ & 0.050 & 0.040 & 0.040 & 0.040 & 0.038 & 0.041 \\
\hline
\end{tabular}

MOI\&

$\begin{array}{lrrrrrr}\mathrm{Ii}_{2} \mathrm{O} & 17.27 & 19.22 & 19.28 & 19.22 & 14.66 & 19.34 \\ \mathrm{MgO} & 4.03 & 4.47 & 4.49 & 4.47 & 5.04 & 3.81 \\ \mathrm{Na}_{2} \mathrm{O} & - & 5.92 & 5.94 & 5.92 & 4.53 & 6.00 \\ \mathrm{Al}_{2} \mathrm{O}_{3} & 6.01 & 6.69 & 6.71 & 6.69 & 5.14 & 6.76 \\ \mathrm{P}_{2} \mathrm{O}_{5} & 7.24 & 37.32 & 29.71 & 37.32 & 26.19 & 37.48 \\ \mathrm{~B}_{2} \mathrm{O}_{3} & - & - & 7.43 & - & - & \\ \mathrm{SiO}_{2} & 64.39 & 25.18 & 25.25 & 25.18 & 19.29 & 25.42 \\ \mathrm{SnO}_{2} & 1.06 & 1.18 & 1.19 & 1.18 & 0.92 & 1.19\end{array}$

(1) $\mathrm{Li}_{2} \mathrm{O}$ Added as 0.701 equivalents LiF

(2) $\mathrm{Na}_{2} \mathrm{O}$ Added as 0.217 equivalents $\mathrm{NaF}$

(3) $\mathrm{Li}_{2} \mathrm{O}$ Added as 0.675 equivalent $\mathrm{LiF}$

(4) $\mathrm{Na}_{2} \mathrm{O}$ Added as 0.209 equivalents $\mathrm{NaF}$

(5) $\mathrm{Li}_{2} 0$ Added as 0.710 equivalents LiF

(6) $\mathrm{Na}_{2} \mathrm{O}$ Added as 0.220 equivalents NaF 
and adding $\mathrm{B}_{2} \mathrm{O}_{3}$ in the amount of 0.260 . This composition, designated as $1 E-11$, formed a low viscosity melt, but did not mature at a firing temperature of $800^{\circ} \mathrm{C}$. The wetting angle did not decrease appreciably. Substitution of $\mathrm{LiF}$ for $\mathrm{Li}_{2} \mathrm{O}$ and $\mathrm{NaF}$ for $\mathrm{Na}_{2} \mathrm{O}$ in the $1 \mathrm{E}-8$ ( $\left.1 \mathrm{E}-12\right)$ reduced the wetting angle. However, the actual maturation and range of maturation temperature was reduced as compared to $1 \mathrm{E}-8$. At $650^{\circ} \mathrm{C}$ for five minutes, the coating was underfiried, whereas at $740^{\circ} \mathrm{C}$ for the same time period, the coating was overfired.

Composition 1E-13, in which the MgO content of $1 \mathrm{E}-12$ increased to 0.120 , resulted in a refractory coating system.

It was concluded that the maturation temperature of this coating was difficult to control. In view of the excellent results obtained in processing of the $5 \mathrm{E}$ series, this coating system was put into abeyance to be used as a "back-up" system. It should be noted, however, that this system may be a viable candidate for the isolation dielectric systems due to the maturation temperature of 650 to $700^{\circ} \mathrm{C}$.

\section{Series 2}

The original composition of this series (Table 3-4) did not form a melt at smelting temperatures of $1500^{\circ} \mathrm{C}$. Changes in the original composition, e.g., (1) increasing CaF for $\mathrm{CaCO}_{3}$ to obtain CaO in $2 E-2$, (3) decreasing the Mgo content to $0: 400$ equivalents $(2 \mathrm{E}-3)$, and (4) further increasing the $\mathrm{B}_{2} \mathrm{O}_{3}$ content to 5.200 equivalents, did not form a liquid when smelted. The development of this coating system was terminated.

\section{Series 3}

These glasses, the compositions of which are shown in Table 3-5, formed high viscosity melts and were too refractory for use as a coating which would mature at $880^{\circ} \mathrm{C}$. Modifications of this coating system (Series 7) are discussed below. 
Table 3-4

Composition of Series 2E Glasses

Oxide 2E-1 2E-2 2E-3 2E-4

\section{Equivalents}

$\begin{array}{lllll}\mathrm{CaO} & 0.125 & 0.125 & 0.238 & 0.238 \\ \mathrm{MgO} & \underline{0.875} & \underline{0.875} & \underline{0.762} & \underline{0.762} \\ \text { Total } & 1.000 & 1.000 & 1.000 & 1.000 \\ \mathrm{Al}_{2} \mathrm{O}_{3} & 0.330 & 0.330 & 0.629 & 0.629 \\ \mathrm{~B}_{2} \mathrm{O}_{3} & 1.382 & 2.382 & 4.537 & 5.200 \\ \mathrm{SiO}_{2} & 2.334 & 2.334 & 4.446 & 4.446\end{array}$

\begin{tabular}{lrrrr} 
& \multicolumn{5}{c}{ Mol } \\
$\mathrm{CaO}$ & 2.48 & 2.07 & 2.24 & 2.11 \\
$\mathrm{MgO}$ & 17.34 & 14.47 & 7.18 & 6.76 \\
$\mathrm{Al}_{2} \mathrm{O}_{3}$ & 6.54 & 5.46 & 5.93 & 5.58 \\
$\mathrm{~B}_{2} \mathrm{~N}_{3}$ & 27.39 & 39.40 & 42.73 & 46.12 \\
$\mathrm{SiO}_{2}$ & 46.25 & 38.60 & 41.90 & 39.43
\end{tabular}




\begin{tabular}{lccc}
\multicolumn{4}{c}{ Table $3-5$} \\
Oxide & $3 \mathrm{E}-1$ & $3 \mathrm{E}-2$ & $3 \mathrm{E}-3$ \\
\multicolumn{4}{c}{ Equivalents } \\
$\mathrm{BaO}$ & 0.133 & 0.612 & 0.673 \\
$\mathrm{ZnO}$ & 0.041 & 0.190 & 0.209 \\
$\mathrm{CaO}$ & 0.043 & 0.198 & 0.118 \\
$\mathrm{MgO}$ & 0.783 & - & - \\
Total & 1.000 & 1.000 & 1.000 \\
$\mathrm{~B}_{2} \mathrm{O}_{3}$ & 1.753 & 8.091 & 8.882 \\
$\mathrm{SiO}_{2}$ & 1.016 & 4.691 & 2.736
\end{tabular}

Mol 응

$\begin{array}{lrcc}\mathrm{BaO} & 3.52 & 4.44 & 5.33 \\ \mathrm{ZnO} & 1.09 & 1.38 & 1.66 \\ \mathrm{CaO} & 1.14 & 1.44 & 0.94 \\ \mathrm{MgO} & 20.79 & - & - \\ \mathrm{B}_{2} \mathrm{O}_{3} & 46.51 & 58.71 & 70.39 \\ \mathrm{SiO}_{2} & 26.96 & 34.03 & 21.68\end{array}$




\section{Series 5}

This coating series, containing dissolved titania as rutile, when smelted and quenched quickly (as when quenched in water) is a clear glass. However, when the glass is reheated and quenched slowly (air quench), through the temperature range of 590 to $650^{\circ} \mathrm{C}$, the titania crystallizes primarily as anatese. Upon further reheating, the anatese converts to rutile. These glasses are highly stable when subjected to thermal excursions, and are therefore, based upon thermal characteristics, an excellent system for the masking dielectric.

The original composition (5E-1), as shown in Table 3-6, exhibited a calculated expansion coefficient of $9.94 \times 10^{-6} /{ }^{\circ} \mathrm{C}$. As the expansion was too high for coatings applied to silicon, changes in the composition were made to obtain more compatible expansion values as in 5E-7 and 5E-8. These latter compositions matured to a high gloss, smooth finish at $880^{\circ} \mathrm{C}$ for 7 minutes.

Coatings $5 E-7$ and $5 E-8$ were evaluated as diffusion barriers by subjecting $P$-type silicon wafers to a diffusion cycle using Emulsitone N-250 phosphorous source. The silicon surface under barrier coated areas was tested by staining techniques and resistivity measurement with no evidence of phosphorous penetration being detected.

Coatings $5 \mathrm{E}-7$ and $5 \mathrm{E}-8$ were further evaluated for their purpose by fabrication of cells after application of the coating. These preliminary experiments yielded cells of poor quality. This result was initially interpreted as being due to contamination of the silicon from the paste during the diffusion step. The titania being suspected as the source of contamination, coating 5E-7-1 was compounded for evaluation. The titania in this coating was replaced entirely by silica. To further identify the contaminant, batches were made in a platinum crucible and a clay crucible. Tests of these materials by 
Table 3-6

Series 5 Compositions

\begin{tabular}{|c|c|c|c|c|}
\hline \multirow[t]{2}{*}{ Oxide } & $5 E-1$ & $5 E-7$ & $5 E-8$ & $5 E-7-1$ \\
\hline & \multicolumn{4}{|c|}{ Equivalents } \\
\hline $\mathrm{Na}_{2} \mathrm{O}$ & 0.505 & $.270(1)$ & .219 & $.270^{(1)}$ \\
\hline $\mathrm{K}_{2} \mathrm{O}$ & 0.211 & .088 & .093 & .088 \\
\hline $\mathrm{CaO}$ & 0.080 & .216 & .234 & .216 \\
\hline $\mathrm{Li}_{2} \mathrm{O}$ & 0.149 & $.276^{(2)}$ & .292 & $.276^{(2)}$ \\
\hline $\mathrm{ZnO}$ & 0.055 & .150 & .162 & .150 \\
\hline Total & 1.000 & 1.000 & 1.000 & 1.000 \\
\hline $\mathrm{B}_{2} \mathrm{O}_{3}$ & 0.644 & 2.752 & 2.932 & 2.752 \\
\hline $\mathrm{TiO}_{2}$ & 1.178 & 1.393 & 1.489 & - \\
\hline $\mathrm{SiO}_{2}$ & 2.669 & 7.338 & 7.823 & 8.731 \\
\hline
\end{tabular}

Mol 웅

$\begin{array}{lrrrr}\mathrm{Na}_{2} \mathrm{O}^{2} & 9.20 & 2.16 & 1.65 & 2.16 \\ \mathrm{~K}_{2} \mathrm{O}^{2} & 3.84 & 0.70 & 0.70 & 0.70 \\ \mathrm{CaO} & 1.46 & 1.73 & 1.77 & 1.73 \\ \mathrm{Li}_{2} \mathrm{O} & 2.71 & 2.21 & 2.20 & 2.21 \\ \mathrm{ZnO} & 1.00 & 1.20 & 1.22 & 1.20 \\ \mathrm{~B}_{2} \mathrm{O}_{3} & 11.73 & 22.05 & 22.14 & 22.05 \\ \mathrm{TiO}_{2} & 21.45 & 11.15 & 11.24 & - \\ \mathrm{SiO}_{2} & 48.61 & 58.78 & 59.07 & 69.94\end{array}$

Expansion

9.9

5.2

5.2

3.5

Coefficient $\left(x 10^{-6}, \bar{C}\right)$

(1) $\mathrm{Na}_{2} \mathrm{O}$ Added as $0.366 \mathrm{NaF}$ (equivalents)

(2) $\mathrm{Li}_{2} \mathrm{O}$ Added as $.479 \mathrm{LiF}$ (equivalents) 
cell fabrication showed no improvement over the original composition, and were possible even inferior.

Another attempt to isolate the contaminant has been initiated. Series 5-E-7-2 through 5-E-7-5 (shown in Table 3-7) are being compounded. The $\mathrm{ZnO}, \mathrm{Na}_{2} \mathrm{O}$ and $\mathrm{Li}_{2} \mathrm{O}$ content was replaced by $\mathrm{P}_{2} \mathrm{O}_{5}(5 \mathrm{E}-7-2)$. This composition did not form a melt. Consequently, the silica content has been incrementally reduced in series 5E-7-3 through 5E-7-5. The contamination hybothesis has been subsequently brought into question, and there is a likelihood of confusion from effects due to other process steps.

During this report period, the viscosity characteristics for fusion flow of the series 5 glasses were determined. The test is conducted as follows:

A one gram sample of -400 mesh powdered glass is formed into a $9.5 \mathrm{~mm}(3,8 \mathrm{in.})$ diameter pellet at a minimum pressure of 28500 pei (1000 lbo load). The pellet is placea on a silicon wafer and fired at $980^{\circ} \mathrm{C}\left(100^{\circ} \mathrm{C}\right.$ above the maturation temperature), in a horizontal position for 1.5 minutes. Without removing from the furnace, the wafer is tilted $90^{\circ}$ and the pellet is fired for 7.0 minutes in the vertical position. The flow of the melted glass is measured to the nearest $0.5 \mathrm{~mm}$.

The fusion flow characteristics of the $5 E-7,5 E-8,5 E-7-1$ and 5E-7-1-P samples are shown in Table 3-8. It can be noted that Series $5 \mathrm{E}-7$ has a longer fusion flow than $5 \mathrm{E}-8$, due to the higher $\mathrm{Na}_{2} \mathrm{O}$ content. A major point of interest is the higher fusion flow of 5E-7-1-P as compared to 5E-7-1. Both series are the same composition, except that $5 E-7-1$ was smelted in a clay crucible, whereas 5E-7-1-P was smelted in a platinum crucible: The observed difference indicates solubility of the clay crucible in the melt. Additionally, the results of substituting silica for titania (5E-7 and 5E-7-1) can be noted. 
Table 3-7

Series 5E Compositions with Added $\mathrm{P}_{2} \mathrm{O}_{5}$

Oxide $\quad 5 E-72 \quad 5 E-73 \quad 5 E-74 \quad 5 E-75$

Equivalents

$\begin{array}{lrrrr}\mathrm{K}_{2} \mathrm{O} & 0.288 & 0.288 & 0.288 & 0.288 \\ \mathrm{CaO} & \frac{0.712}{1.000} & \frac{0.712}{1.000} & \frac{0.712}{1.000} & \frac{0.712}{1.000} \\ \text { Total } & 1.000 & & \\ \mathrm{~B}_{2}{ }^{0} 3 & 9.041 & 9.041 & 9.041 & 9.041 \\ \mathrm{SiO}_{2} & 38.676 & 20.000 & 15.000 & 10.000 \\ \mathrm{P}_{2}{ }^{0} 5 & 3.505 & 3.505 & 3.505 & 3.505\end{array}$

Mo1\%

$\begin{array}{lrrrr}\mathrm{K}_{2}{ }^{0} & 0.55 & 0.86 & 1.01 & 1.22 \\ \mathrm{CaO} & 1.36 & 2.12 & 2.49 & 3.02 \\ \mathrm{~B}_{2}{ }^{0}{ }_{3} & 17.31 & 26.95 & 31.67 & 38.40 \\ \mathrm{SiO}_{2} & 74.06 & 59.62 & 52.55 & 42.47 \\ \mathrm{P}_{2}{ }^{0} 5 & 6.71 & 10.45 & 12.28 & 14.89\end{array}$

Expansion

Coefficient

$3 \cdot 3$

3.4

3.5

3.7

$\left(\mathrm{x} 10^{-6},{ }^{\circ} \mathrm{C}\right.$ ) 


$$
\begin{gathered}
\text { Table } 3-8 \\
\text { Flow of Series } 5 \\
\text { at } 980^{\circ} \mathrm{C} \text { and } 7 \text { Minutes }
\end{gathered}
$$

$\begin{array}{lll}\text { Test } & \begin{array}{l}\text { Series } \\ \text { Number }\end{array} & \begin{array}{c}\text { Flow } \\ (\mathrm{mm})\end{array} \\ 1 & 5 \mathrm{E}-7 & 29.5 \\ 2 & 5 \mathrm{E}-8 & 23.5 \\ 3 & 5 \mathrm{E}-7-1 & 24.3 \quad \text { Lower } \mathrm{Na}_{2} 0 \text { content than } 5 \mathrm{E}-7 \\ 4 & 5 \mathrm{E}-7-1-\mathrm{P} & 39.3 \quad \text { *Smelted in clay crucible } \\ & \text { No titania in } 5 \mathrm{E}-7-1 \text { and } 5 \mathrm{E}-7-1-\mathrm{P}\end{array}$


This testing will be valuable in assessing the effect of changes in composition upon maturing temperature. This application of the test will be illustrated in the discussion of the series 7 glasses.

Coatings $5 \mathrm{E}-7$ and $5 \mathrm{E}-8$ were evaluated for thermal endurance. The coatings were cycled ten times from room temperature to $880^{\circ} \mathrm{C}$ and back to room temperature (Series A). The color of the coatings changed from a blue white to a yellow white indicating that the crystallized titania was converted from anatase to rutile. Cursory examination of the exposed silicon adjacent to the coating indicated a blue haze which became more pronounced as the thermal cycling progressed. The coatings were also sequentially cycled from room temperature to 880,800700 and 600 and $500^{\circ} \mathrm{C}$ (Series B).

Coated silicon wafers, representative of both thermal cycling sequences, were examined with the Scanning Electron Microscope. The area adjacent to the coatings were examined with the microprobe.

\section{Series 7}

The study of this series was initiated as a back-up to series 5 . These coatings, as shown in Table 3-9, are free of $\mathrm{Na}_{2} \mathrm{O}$ and $\mathrm{Li}_{2} \mathrm{O}$. The initial compositions (7E-1 and 7E-3) evaluated for degree of maturation at a firing temperature of $880^{\circ} \mathrm{C}$ for 7 minutes indicated an overfired condition. Additionally, the expansion coefficient (calculated) was too high for application to silicon. The magnesia content was increased in $7 E-3$ to obtain a reduced coefficient of expansion and at the same time increase the maturation temperature. From examination of Table 3-9 the reduction in expansion coefficient can be noted. 
Table 3-9. Series 7 Compositions

\begin{tabular}{|c|c|c|c|c|c|c|c|c|}
\hline oxide & $7 E-1$ & $7 E-3$ & $7 E-4$ & $7 E-5$ & $7 E-6$ & $7 E-7$ & $7 E-8$ & $7 E-9$ \\
\hline \multicolumn{9}{|c|}{ Equivalents } \\
\hline $\mathrm{BaO}$ & 0.412 & 0.395 & 0.395 & 0.359 & 0.329 & 0.304 & 0.198 & 0.260 \\
\hline $\mathrm{zno}$ & 0.088 & 0.084 & 0.084 & 0.076 & 0.070 & 0.065 & 0.042 & 0.055 \\
\hline $\mathrm{CaO}$ & 0.089 & 0.085 & 0.085 & 0.077 & 0.071 & 0.065 & 0.042 & 0.056 \\
\hline MgO & $\underline{0.412}$ & $\underline{0.436}$ & $\underline{0.436}$ & 0.487 & $\underline{0.530}$. & $\underline{0.566}$ & $\underline{0.718}$ & $\underline{0.629}$ \\
\hline Total & 1.001 & 1.000 & 1.000 & 0.999 & 1.1000 & 1.000 & 1.000 & 1.000 \\
\hline $\mathrm{Al}_{2} \mathrm{O}_{3}$ & 0.014 & - & - & - & - & - & - & - \\
\hline $\mathrm{B}_{2} \mathrm{O}_{3}$ & 0.634 & 0.766 & 0.766 & 0.696 & 0.538 & 0.489 & 0.386 & 0.506 \\
\hline $\mathrm{SiO}_{2}$ & 0.895 & 0.857 & 0.657 & 0.597 & 0.548 & 0.505 & 0.329 & 0.433 \\
\hline $\mathrm{ZnO}_{2}$ & 0.029 & - & - & - & - & - & - & - \\
\hline \multicolumn{9}{|c|}{ Mol : } \\
\hline $\mathrm{BaO}$ & 16.01 & 15.06 & 16.30 & 15.66 & 15.05 & 14.52 & 11.52 & 13.41 \\
\hline Zno & 3.42 & 3.20 & 3.47 & 3.32 & 3.20 & 3.10 & 2.45 & 2.85 \\
\hline $\mathrm{CaO}$ & 3.46 & 3.24 & 3.51 & 3.36 & 3.25 & 3.10 & 2.48 & 2.89 \\
\hline MgO & 16.01 & 16.62 & 17.99 & 21.25 & 24.25 & 27.03 & 41.88 & 32.43 \\
\hline $\mathrm{Al}_{2} \mathrm{O}_{3}$ & .0 .54 & - & - & - & - & - & - & - \\
\hline $\mathrm{B}_{2} \mathrm{O}_{3}$ & 24.64 & 29.20 & 31.61 & 30.37 & 29.19 & 28.13 & 22.51 & 26.09 \\
\hline $\mathrm{SiC}_{2}$ & 34.78 & 32.67 & 27.12 & 26.45 & 25.07 & 24.12 & 19.16 & 22.32 \\
\hline $\mathrm{ZnC}_{2}$ & 1.13 & - & - & - & - & - & - & - \\
\hline $\begin{array}{l}\text { Expansion } \\
\text { Coefficient } \\
\left(x 10^{-6} /{ }^{\circ} \mathrm{C}\right)\end{array}$ & 5.2 & 4.9 & 5.0 & 4.6 & 4.5 & 4.4 & 3.9 & 4.3 \\
\hline
\end{tabular}


Based on the work on Series 5 discussed above, it was decided that the series 7 glasses, should exhibit a fusion flow length between 20 and $30 \mathrm{millimeters}$ at an exposure of $980^{\circ} \mathrm{C}$, with $1 \frac{1}{2}$ minutes in the horizontal position and 7 minutes vertically. Based on the data shown in Table 3-10 all of the glasses, with the exception of $7 \mathrm{E}-8$, would be overfired at a temperature of $880^{\circ} \mathrm{C}$. Coating $7 \mathrm{E}-8$ would be underfired. As the magnesia content was increased above that shown in 7E-5, adherence decreased drastically. The adherence was restored upon the addition of 5 parts of Lepo Fluoride $\left(\mathrm{PbF}_{2}\right)$ to 100 parts by weight of glass.

Mixtures of glasses $7 E-6,7 E-7$ and $7 E-8$ were made to determine the optimum magnesia and lead fluoride content to obtain good adherence and maturation at $880^{\circ} \mathrm{C}$ (Table 3-11). Adherence was noted only at lead fluoride contents of 5 parts per 100 parts by weight of glass. The composition of 7E-8-1 was determined. on the basis of tests 4,5 and 10 through 17 . An anomoly exists in tests 19 through 21 . It would be expected that an increasing lead fluoride content should increase the fusion flow. However, since lead fluoride contents less than 5.0 did not result in adherence, the reasons for the anomoly may be academic. Coating 7E-8-1 will be prepared for evaluation as a diffusion barrier. 
Table 3-10

Flow of series 7

at Various Times and Temperatures

$\begin{array}{llccrl}\text { Test } & \begin{array}{l}\text { Series } \\ \text { Number }\end{array} & \begin{array}{c}\text { Time* } \\ (\mathrm{min})\end{array} & \begin{array}{c}\text { Temp } \\ (\mathrm{O} C)\end{array} & \begin{array}{c}\text { Flow } \\ (\mathrm{mm})\end{array} & \text { Remarks } \\ 1 & 7 \mathrm{E}=2 & 980 & 4 & >46.0 & \\ 2 & 7 \mathrm{E}-3 & 980 & 3 & 27.0 & \\ 3 & 7 \mathrm{E}-4 & 980 & 2 & >46.0 & \\ 4 & 7 \mathrm{E}-7 & 980 & 7 & >51.0 & \\ 5 & 7 \mathrm{E}-8 & 980 & 7 & 13.5 & \text { (devitrified) } \\ 6 & 7 \mathrm{E}-5 & 900 & 4 & 40.8 & \\ 7 & 7 \mathrm{E}-6 & 900 & 4 & 36.8 & \\ 8 & 7 \mathrm{E}-7 & 900 & 4 & 32.3 & \\ 9 & 7 \mathrm{E}-8 & 900 & 4 & 17.8 & \end{array}$


Table 3-11

Flow of Series $7 *$ a $980^{\circ} \mathrm{C}, 7 \mathrm{Min}$.

$\begin{array}{rllllll}\text { Test No. } & 7 \mathrm{E}-6 & 7 \mathrm{E}-7 & 7 \mathrm{E}-8 & 7 \mathrm{E}-8-1 & \mathrm{PbF}_{2} & \begin{array}{l}\text { Flow } \\ (\mathrm{mm})\end{array} \\ 4 & - & 100 & - & - & 0 & 51.0 \\ 5 & - & - & 100 & - & 0 & 13.5 \text { (Devitrified) } \\ 10 & - & 50 & 50 & - & 0 & 19.0 \\ 11 & - & 70 & 30 & - & 0 & 34.0 \\ 12 & - & 70 & 30 & - & 2.5 & 47.5 \\ 13 & - & 70 & 30 & - & 5.0 & 48.5 \\ 14 & - & - & 100 & - & 5.0 & 0 \\ 15 & 40 & - & 60 & - & 5.0 & 18.0 \\ 16 & 45 & - & 55 & - & 5.0 & 20.5 \\ 17 & 50 & - & 50 & - & 5.0 & 48.5 \\ 18 & - & - & - & 100 & 0.0 & 46.8 \\ 19 & - & - & - & 100 & 5.0 & 22.0 \\ 20 & - & - & - & 100 & 4.5 & 33.5 \\ 21 & - & - & - & 100 & 4.0 & 24.5\end{array}$

*Parts by Weight 


\subsection{2 $\underline{\mathrm{P}^{+} \text {Back Contact }}$}

A number of cell fabrication experiments have been carried out in order to understand the effectiveness of an Al back contact metallization both as ohmic contact and its ability to remove the diffused $\mathrm{N}^{+}$layer. These experiments are summarized in Tablc 3-12. In all cases cells were tabricated on 2 inch diameter $10 \mathrm{ohm} \mathrm{cm} \mathrm{P-type} \mathrm{round} \mathrm{wafers.} \mathrm{Surfaces} \mathrm{were} \mathrm{prepared}$ by a damage removal etch in hot $30 \%$ hydroxide with no texturizing. Junctions were formed at a depth of $0.3 \mu \mathrm{m}$ by phosphine diffusion. Front contacts were evaporated Ti-Pd-Ag after removal of the diffusion oxide by 10 second immersion in $5 \% \mathrm{HF}$. Back contact preparation was varied as indicated in Table 3-12. No AR coat was applied. After cell processing was completed, $2 \times 2 \mathrm{~cm}$ cells were cut from the round disks in order to provide edge clean up.

The first experiment demonstrates the problem of producing a cell without removing the diffused $\mathrm{N}^{+}$layer. Once the $\mathrm{N}^{+}$layer is removed by back etching (experiment 2), the back contact is able to make ohmic contact. In this experiment, the cells have a relatively low $V_{o c}$ and $I_{g c}$ characteristic of $10 \mathrm{shm}-\mathrm{rm}$ material without a back field. On firing an Al bark sontact to producc a $\mathrm{P}^{+}$layer (experiment 3 ), the $\mathrm{V}_{\text {oc }}$ increased $10 \%$ and the $\mathrm{I}_{\mathrm{sc}_{+}}$ increased 5\%. The ability of the $\mathrm{P}^{+}$layer to remove the $\mathrm{N}^{+}$ layer during firing is shown in experiment 4. Comparison of this experiment with the preceding one suggests that the back etch process used in experiment 3 somehow contributes to degradation of cell, possibly by damage to the front surface. Experiment 5 in which the aluminum back was fired at a lower temperature indicates the sensitivity of the process to the firing cycle. 
Table 3-12

Formation of $\mathrm{P}^{+}$Back contact Through

Diffused Layers

\begin{tabular}{|c|c|c|c|c|c|c|c|c|}
\hline Exp. & $\begin{array}{l}\text { Back } \\
\text { Etch }\end{array}$ & $\begin{array}{c}\text { Back } \\
\text { Contact }\end{array}$ & & $\begin{array}{r}\text { Firing } \\
\text { Conditio } \\
\end{array}$ & & $\begin{array}{c}E_{O C} \\
\mathrm{mV}\end{array}$ & $\begin{array}{l}I_{s c} \\
m A\end{array}$ & $\begin{array}{c}I_{400} \\
\mathrm{~mA} \\
\end{array}$ \\
\hline 1. & no & Evap. & & none & & \multicolumn{3}{|c|}{ no response } \\
\hline \multirow[t]{3}{*}{2 . } & yes & Evap. & & none & & $\begin{array}{l}542 \\
538 \\
538 \\
538 \\
541 \\
541 \\
536 \\
541 \\
539 \\
538 \\
\end{array}$ & $\begin{array}{l}89 \\
88 \\
86 \\
85 \\
89 \\
90 \\
86 \\
89 \\
87 \\
88 \\
\end{array}$ & $\begin{array}{l}88 \\
87 \\
85 \\
84 \\
88 \\
89 \\
85 \\
88 \\
86 \\
87 \\
\end{array}$ \\
\hline & & & & & $\overline{\mathrm{X}}$ & 539 & 87.7 & 86.7 \\
\hline & & & & & $\sigma$ & 1.87 & 1.55 & 1.55 \\
\hline \multirow[t]{3}{*}{3.} & yes & Paste & Al & $\begin{array}{l}10 \mathrm{sec} \\
900^{\circ} \mathrm{C}\end{array}$ & & $\begin{array}{l}600 \\
597 \\
596 \\
589 \\
585 \\
588 \\
571 \\
563 \\
592 \\
580 \\
\end{array}$ & $\begin{array}{l}94 \\
96 \\
98 \\
95 \\
94 \\
95 \\
94 \\
92 \\
96 \\
93 \\
\end{array}$ & $\begin{array}{l}83 \\
96 \\
96 \\
92 \\
93 \\
93 \\
90 \\
89 \\
95 \\
91 \\
\end{array}$ \\
\hline & & & & & $\overline{\mathrm{X}}$ & 586 & 94.7 & 91.8 \\
\hline & & & & & $\sigma$ & 11.2 & 1.61 & 3.71 \\
\hline \multirow[t]{3}{*}{4.} & no & Paste & Al & $\begin{array}{l}10 \text { sec } \\
900^{\circ} \mathrm{C}\end{array}$ & & $\begin{array}{l}604 \\
604 \\
601 \\
600 \\
603 \\
596 \\
605 \\
602 \\
601 \\
605 \\
602 \\
600 \\
604 \\
604 \\
\end{array}$ & $\begin{array}{l}97 \\
96 \\
96 \\
97 \\
95 \\
96 \\
96 \\
97 \\
96 \\
95 \\
97 \\
96 \\
96 \\
96 \\
\end{array}$ & $\begin{array}{l}95 \\
95 \\
95 \\
96 \\
95 \\
95 \\
95 \\
96 \\
95 \\
94 \\
96 \\
96 \\
95 \\
95 \\
\end{array}$ \\
\hline & & & & & $\begin{array}{l}\bar{X} \\
\sigma\end{array}$ & $\begin{array}{l}602 \\
2.40\end{array}$ & $\begin{array}{l}96.1 \\
0.63\end{array}$ & $\begin{array}{l}95.2 \\
0.558\end{array}$ \\
\hline & & & & $-31-$ & & & & \\
\hline
\end{tabular}


Table 3-12 (continued)

Formation of $\mathrm{P}^{+}$Back Contact Through

Diffused Layers

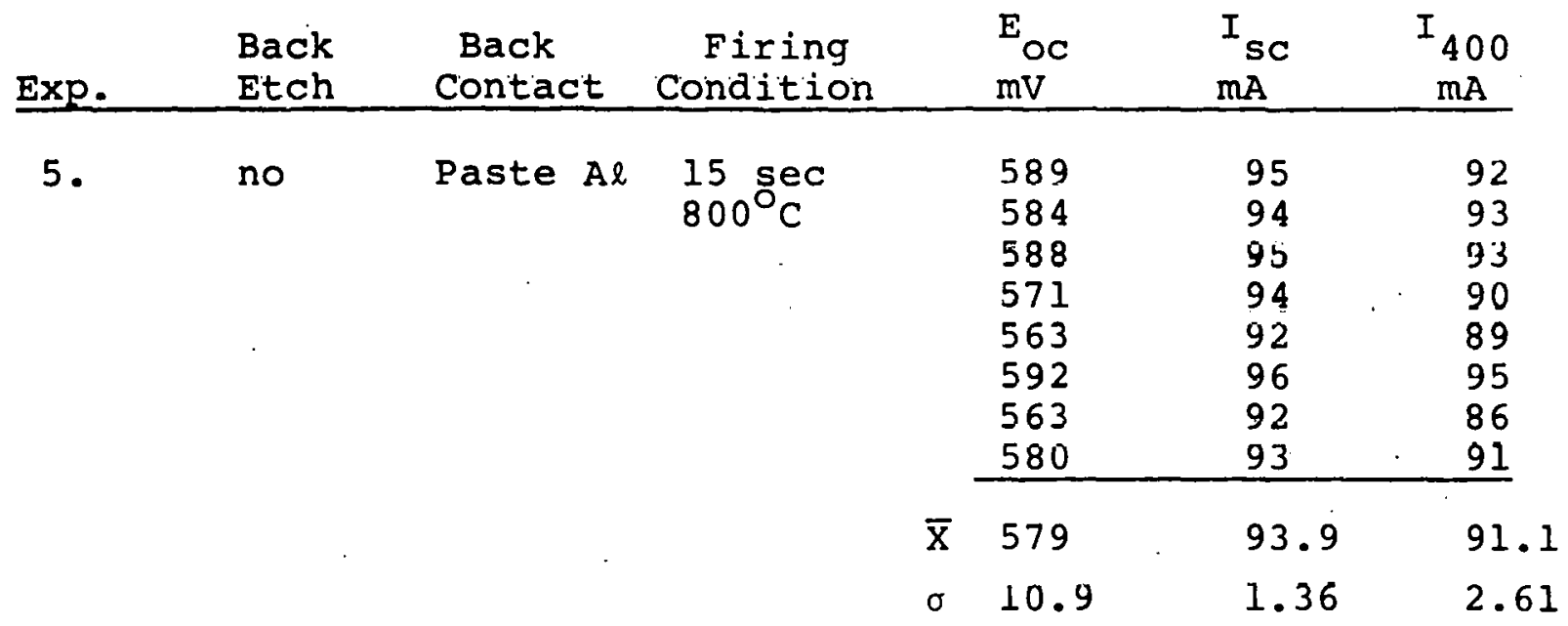




\subsubsection{Diffusion}

During the present quarter diffusion process work has concentrated on the use of Emulsitone N-250 diffusion source. This source material was successfully applied by spraying and contact transfer techniques to yield uniform junctions and efficient solar cells. It was found that if the applied layer is too thick, it may flake during drying. This observation probably accounts for the unsatisfactory performance previously observed with this source. (2) This thickness limitation was less stringent for texturized than polished or semi-polished cells. Better control of the sprayed layer thickness was achieved through dilution of the $\mathrm{N}-250$ by the addition of anhydrous isopropyl alcohol to $30 \%$ volume concentration. The applied diffusion source was fired in a nitrogen atmosphere with a 25 minute ramp from $700^{\circ} \mathrm{C}$ up to $900^{\circ} \mathrm{C}$, a ten minute drive at this temperature and a 25 minute ramp back down to $700^{\circ} \mathrm{C}$ in all cases.

This diffusion cycle for $\mathrm{N}-250$ was tested on four sets of cells with variations in surface preparation and method or dopant application. In all cases the cells were fabricated on $10 \mathrm{ohm} \mathrm{cm}$ silicon wafers with evaporated contacts and $\mathrm{P}+$ hack surface field $2 \mathrm{~cm} \times 2 \mathrm{~cm}$ cells were cut from rounds after completion of all processing. Results are reported in Table 2-13, together with the surface, treatment and method of application. 
Table 3-13

Output parameters at AMO for non-AR coated cells prepared by diffusion from $\mathrm{N}-250$ source with a diffusion cycle of 25 minutes ramp from $700^{\circ} \mathrm{C}$ to $900^{\circ} \mathrm{C}, 10$ minutes at $900^{\circ} \mathrm{C}, 25$ minute ramp from $900^{\circ} \mathrm{C}$ to $700^{\circ} \mathrm{C}$.

\begin{tabular}{|c|c|c|c|c|}
\hline Experiment & Treatment & $\mathrm{V}_{\mathrm{OC}}$ & $I_{\text {sc }}$ & $I_{400}$ \\
\hline \multirow[t]{3}{*}{1} & \multirow[t]{3}{*}{$\begin{array}{l}\text { Surface texturized to a matte } \\
\text { finish. Undiluted } \mathrm{N}-250 \text { applied } \\
\text { by spraying. Some diffusion } \\
\text { residue was resistant to } \mathrm{HF} \text {, and } \\
\text { acted as an AR coating. }\end{array}$} & $\begin{array}{l}620 \\
616 \\
617 \\
619 \\
614 \\
619 \\
616 \\
616\end{array}$ & $\begin{array}{l}141 \\
140 \\
137 \\
141 \\
141 \\
137 \\
139 \\
139\end{array}$ & $\begin{array}{l}140 \\
138 \\
135 \\
139 \\
137 \\
135 \\
138 \\
137\end{array}$ \\
\hline & & 517.1 & 139.4 & $13 \% .4$ \\
\hline & & 1.90 & 1.58 & 1.65 \\
\hline \multirow[t]{3}{*}{2.} & \multirow[t]{3}{*}{$\begin{array}{l}\text { Surface texturized to form } \\
\text { sharply defined pyramids. } \\
\text { Undiluted } \mathrm{N}-250 \text { applied by } \\
\text { spraying. Diffusion glass } \\
\text { removed by HF soak ( } 30 \text { sec. } \\
\text { in 5\% HF) }\end{array}$} & $\begin{array}{l}613 \\
613 \\
612 \\
614 \\
612 \\
613 \\
614 \\
616 \\
615\end{array}$ & $\begin{array}{l}137 \\
132 \\
129 \\
129 \\
138 \\
139 \\
134 \\
135 \\
134\end{array}$ & $\begin{array}{l}134 \\
129 \\
128 \\
120 \\
128 \\
130 \\
130 \\
130 \\
132\end{array}$ \\
\hline & & 613.6 & 134.1 & 129.9 \\
\hline & & $1: 26$ & 3.41 & 1.91 \\
\hline \multirow[t]{3}{*}{3.} & \multirow[t]{3}{*}{$\begin{array}{l}\text { Surface texturized to a matte } \\
\text { finish. N-250 applied by con- } \\
\text { tact transfer from Dextilose } \\
\text { paper. Diffusion glass. } \\
\text { removed by HF soak ( } 30 \text { sec } \\
\text { in 5z HF) }\end{array}$} & $\begin{array}{l}616 \\
612 \\
613 \\
614 \\
614 \\
618 \\
612 \\
612 \\
616 \\
618 \\
618 \\
616\end{array}$ & $\begin{array}{l}128 \\
129 \\
127 \\
134 \\
128 \\
137 \\
132 \\
132 \\
130 \\
130 \\
129 \\
129\end{array}$ & $\begin{array}{l}126 \\
121 \\
124 \\
126 \\
124 \\
134 \\
131 \\
131 \\
128 \\
129 \\
127 \\
127\end{array}$ \\
\hline & & 614.9 & 130.4 & 127.3 \\
\hline & & 2.29 & 2.75 & 3.42 \\
\hline
\end{tabular}




\section{Table 3-13 (continued)}

Experiment Treatment

OC

$I_{\text {SC }}$

$I_{400}$

4.

$\begin{array}{lllr}\text { Surface smooth etched in 30\% } & 613 & 107 & 106 \\ \text { NaOH. N-250 applied by contact } & 610 & 112 & 108 \\ \text { transfer from Dextilose paper. } & 604 & 108 & 91 \\ \text { Diffusion glass removed by HF } & 606 & 106 & 94 \\ \text { soak (10 sec in 5\% HF) } & 609 & 113 & 99 \\ & 610 & 110 & 87 \\ & 612 & 106 & 93 \\ & 613 & 108 & 92 \\ & 602 & 107 & 93 \\ & \bar{x} 608.4 & 108.6 & 95.9 \\ & \sigma 3.77 & 2.40 & 6.64\end{array}$


The first group of samples were sprayed with a heavy layer of undiluted $\mathrm{N}-250$. Care was necessary in order to prevent flaking upon drying; polished samples had a higher tendency for flaking. A stain layer remained on the surface after a $58 \mathrm{HF}$ etch following diffusion. These cells tested very good $\mathrm{P}^{+}$. The group 2 cells were sprayed with $\mathrm{N}-250$ that had been diluted with $30 \%$ IPA. Very thin layers of $\mathrm{N}-250$ were applied and no stain layer remained after the $5 \%$. HF etch. Theae cells also pruvided very good response, however, $I_{S C}$ is lower than group 1, suggesting that the stain in that group acted as an antireflective coating. $\mathrm{N}-250$ was applied to the third group by means of a contact transfer and produced good cells. Contact transfer of $\mathrm{N}-250$ onto nontextured cells (group 4) also produced good cells with a reduced output resulting from lack of texturing.

Additional experiments were carried out on $2 \mathrm{ohm}-\mathrm{cm}$ wafers. In these the diluted $\mathrm{N}-250$ source was sprayed on and diffused at a lower temperature $\left(850^{\circ} \mathrm{C}\right.$ for 30 minutes). In one experiment an aluminum back was applied, in the other an evaporated back etching. The results are reported in Table 3-14. In both cases good cells were obtained with output at load comparable to cells in the previous experiments. In this experiment the aluminum back did not cause the expected increase in open circuit voltage and short circuit current. 
Output parameters at AMO for non-AR coated cells prepared by diffusion from $\mathrm{N}-250$ source with a diffusion cycle of 20 minutes ramp from $700^{\circ} \mathrm{C}$ to $850^{\circ} \mathrm{C}, 30$ minutes at $850^{\circ} \mathrm{C}, 20$ minute ramp from $900^{\circ} \mathrm{C}$ to $700^{\circ} \mathrm{C}$.

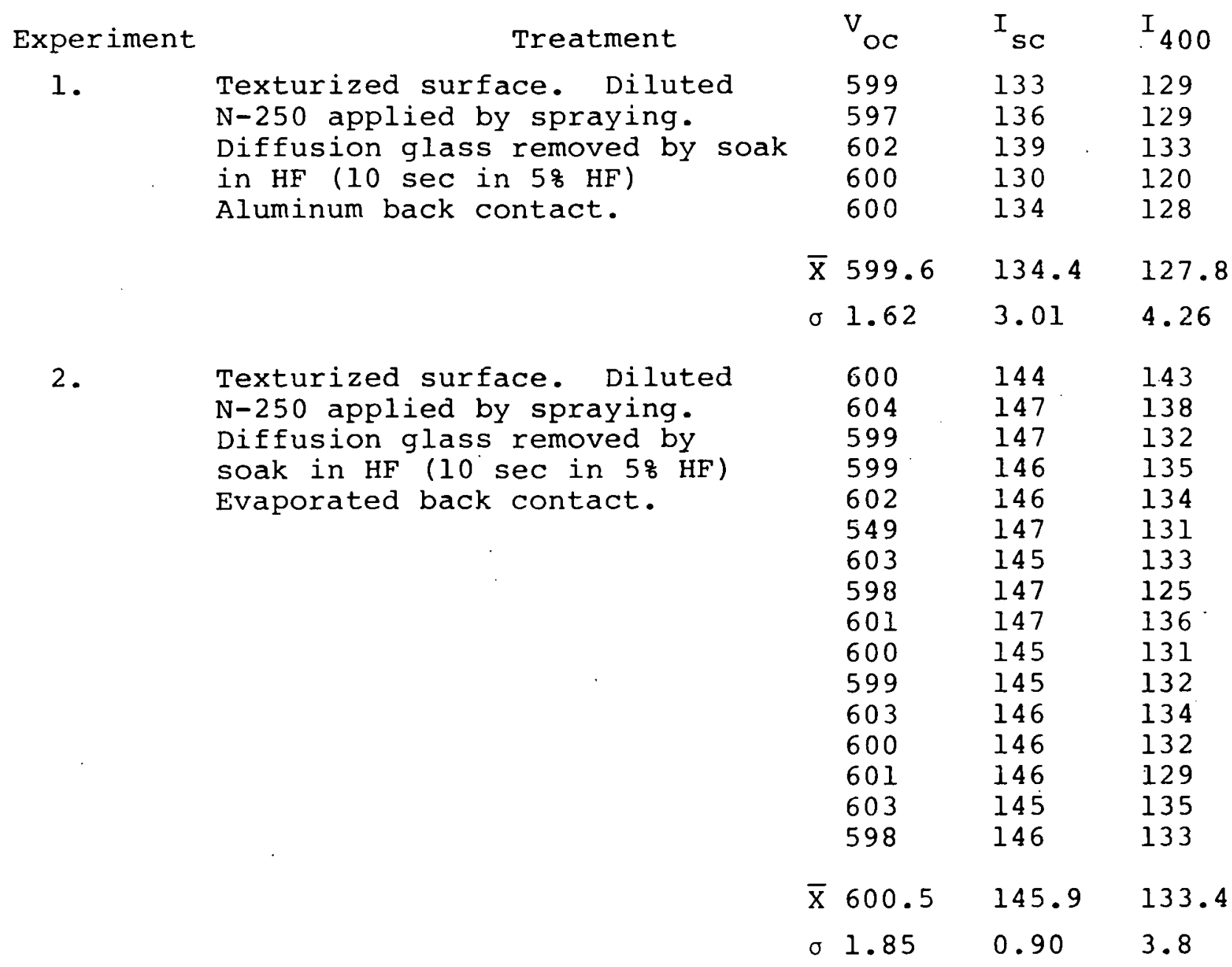


3.3 METALIIZATION

3.3.1 Front Contacts

During the current period, work was continued on the use of fritted thick film pastes as contact metallization. The commercial silver pastes listed in Table 3-15 have been evaluated with respect to output of cells fabricated with various firing eycles. (1) 'l'hose pastes indicated by asterisks are those giving better results as received from the vendor.

Guided by the hypothesis of oxidative attack of the silicon accomplied by solution of the $\mathrm{siO}_{2}$ in the frit during the firing process, we have investigated the effects of varying the amount of frit in the paste and additions of $N$ type diffusion sources. In general both of these lead to improved performance.

The optinum frit content is usually less than that normally present in commercial pastes and appears to be abaut $2 \%$. The effect of reducing the frit content of Cermallny 4450 silver paste by the addition of Thick Film systems A-250 fritless silver paste is shown in Figure 7 .

Emulsitone $233(\mathrm{Sb})$ and Transene N-Diffusol. have heen found to be useful additives in the amounts of about $2 \%$ by weight. The effect of adding Emulsitone $233(\mathrm{Sb})$ to Electro-Science Laboratories 590 silver paste is shown in Figure 8. These diffusion source additives irequently have the effect of reducing the sensitivity of the time-temperature firing cycle.

\subsubsection{Solder Pads}

One disadvantage of an aluminum back contact is the anodic nature of aluminum. The galvanic series for aluminum and some 
Table 3-15

COMMERCIAL AG PASTES

EVALUATED FOR USE AS COLLECTOR METALLIZATION

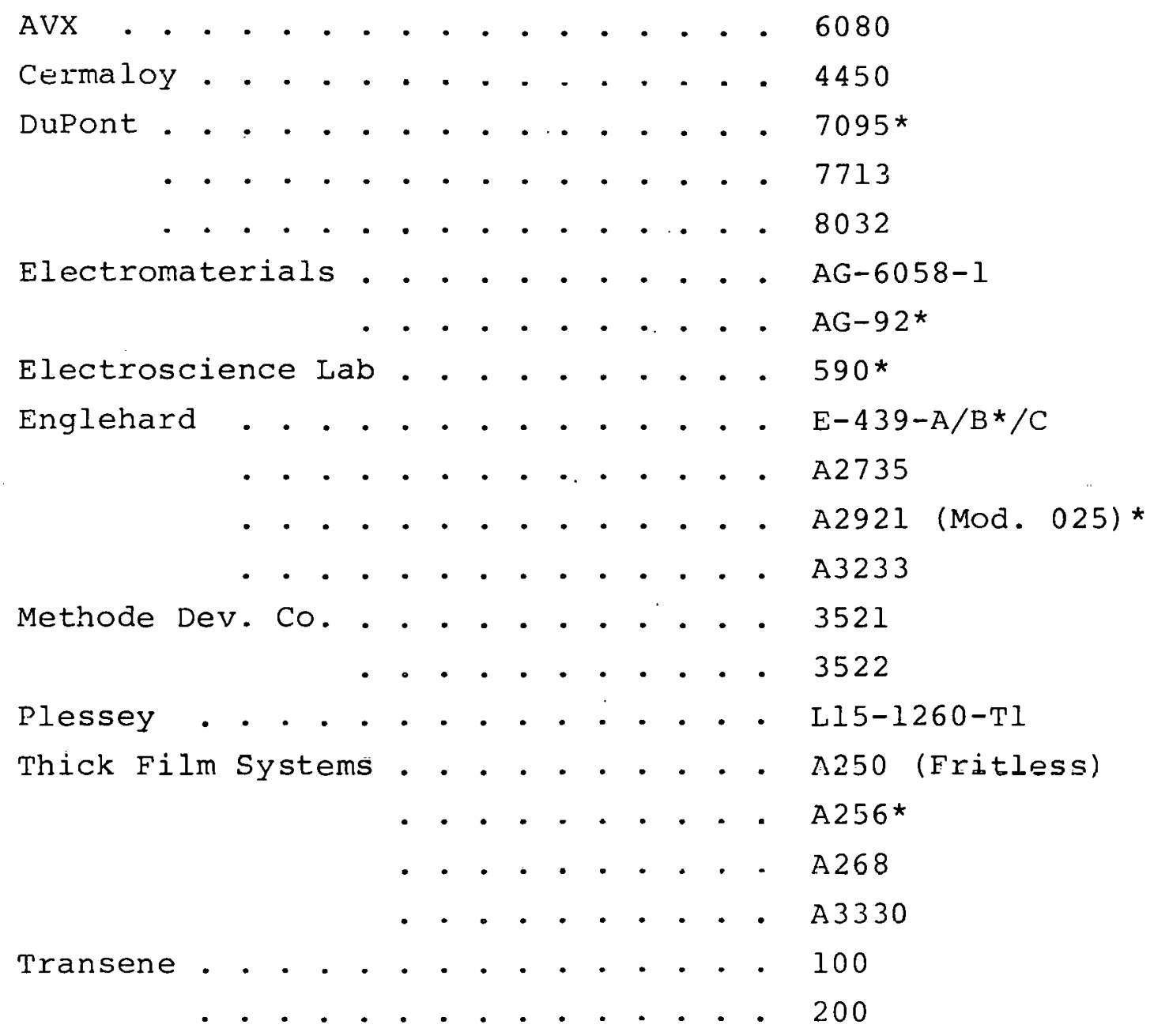

*Pastes giving better results as received from vendor. 


$$
\begin{gathered}
\text { Figure } 3-17 \\
\text { IMPROVEMENT OF CURVE SHAPE } \\
\text { BY REDUCING FRIT CONTENT OF PASTE }
\end{gathered}
$$

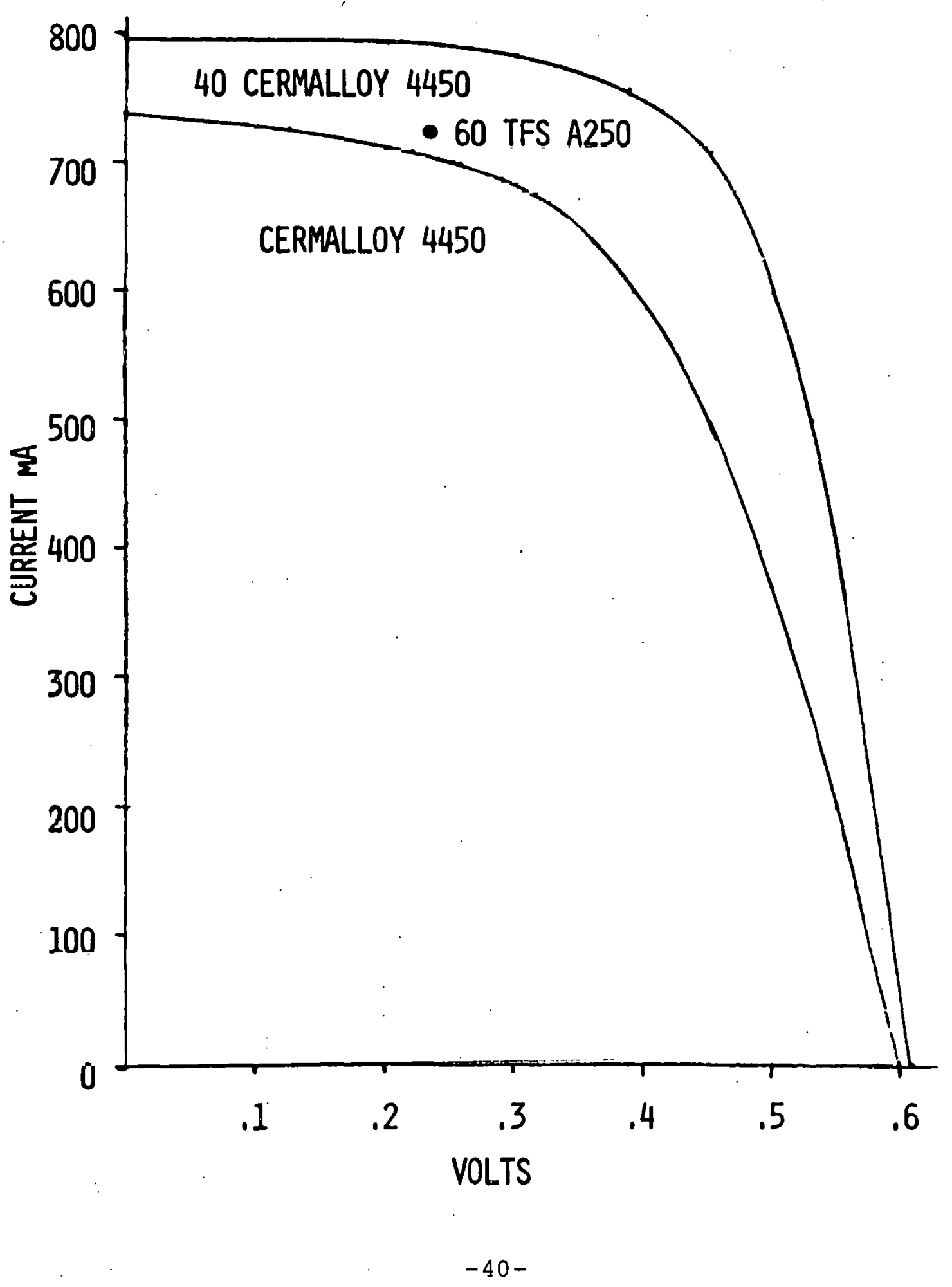


Figure 18

EFFECT OF N-TYPE DIFFUSION SOURCE ADDITION TO COMMERCIAL SILVER PASTE ON SOLAR CELL PERFORMANCE

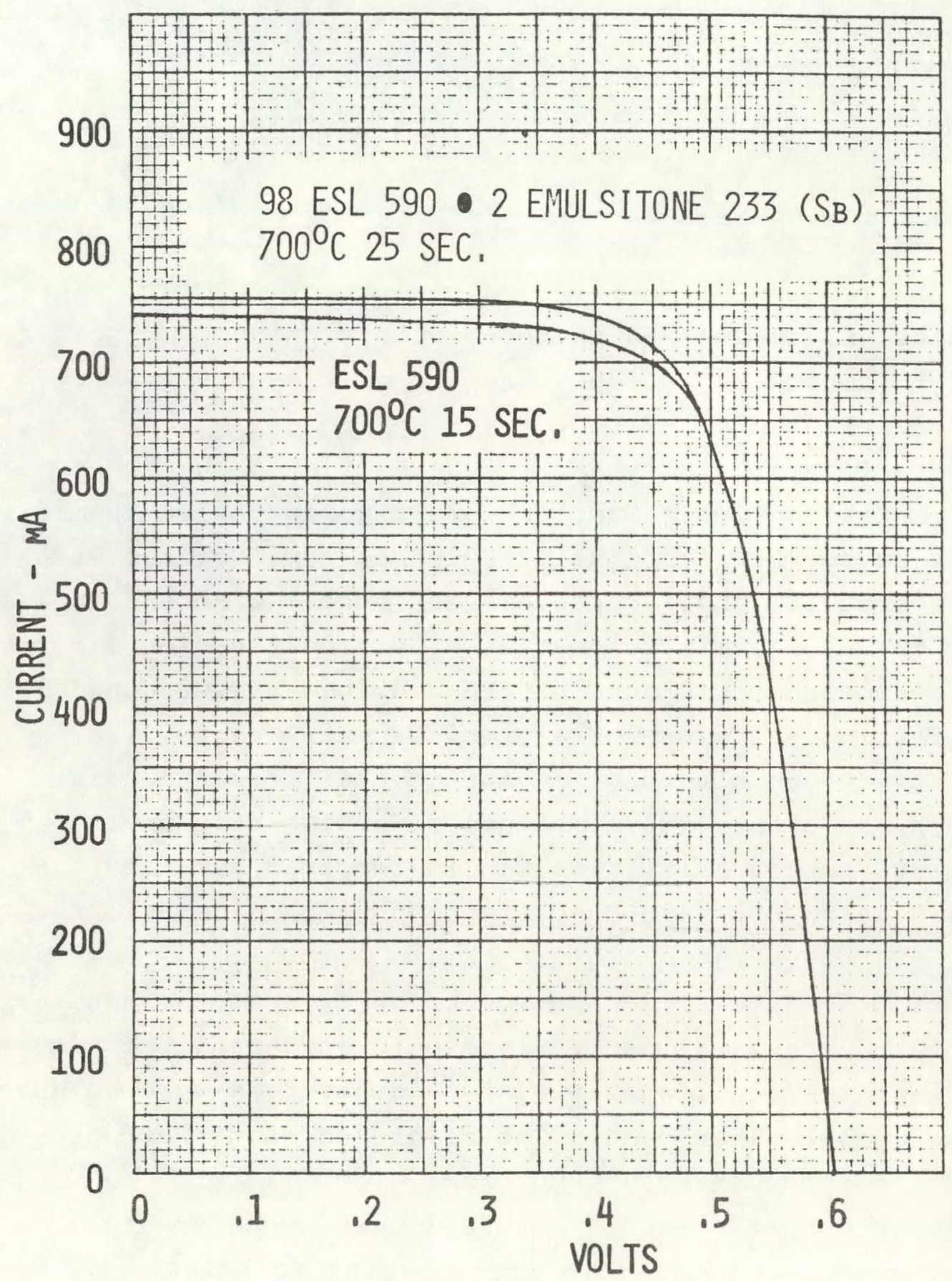


other important metals is:

\author{
$\underline{\text { ANODE }}$ \\ zinc \\ aluminum \\ lead-tin solders \\ copper \\ nickel \\ silver \\ CATHODE (least corrodable)
}

The use of a silver solder pad on top of the aluminum for soldering may lead to corrosion and delamination of the silver.

A fritted and a frit-free silver paste were printed on top of the aluminum metallization. Samples were exposed to $100 \%$ humidity at $65^{\circ} \mathrm{C}$ for 7 days. Both materials peeled to some degree, with the firt-free material showing poorer adherence. Zinc and indium additives to the aluminum were tested. This modification did not improve the corrosion resistance of the aluminum-silver couple in humidity testing. The use of a precious metal paste (TRS $3402 \mathrm{Pd}-\mathrm{Ag}$ ) offered no adherence advantage over less expensive materials such as DuPont 7095. The use of a high frit paste such as TFS 3303 ( $~ 15 \%$ frit) resulted in improved humidity tolerance with an unfortunate concurrent loss in solderability.

Tin and $90 \%$ tin-10\% zinc solder pads were applied to the aluminum back contact metallization by ultrasonic soldering techniques. Interconnects of tin and lead-tin plated copper mesh were soldered to cells with these solder pads. These interconnects were prepulled at $90^{\circ}$ to approximately 1000 grams, Table 3-16. The cells with interconnect that did not fail during the pre-pull 
test were subjrsted to 1008 humidity at $70^{\circ} \mathrm{C}$ for 168 hours. The cell interconnects were then re-pulled to failure (Table 3-16). These combinations demonstrated good adherence and tolerance to humidity. The tin-zinc pads experienced a small degree of corrosion whereas the tin did not change during the exposure. 
Table 3-16

BACK CONTACT METALLIZATION

SOLDER TO ALUMLNUM $\mathrm{p}^{+}$

by Ultrasonic Soldering Pad

\begin{tabular}{|c|c|c|c|c|c|}
\hline Cell No. & Pad & Solder & FIux & $\begin{array}{l}\text { (grams) } \\
\text { (gram }\end{array}$ & Humid. (grams) \\
\hline $\begin{array}{l}1 \\
23 \\
24 \\
25 \\
26\end{array}$ & $\begin{array}{l}\text { Sn } \\
" 1 \\
" \\
" \\
"\end{array}$ & $\begin{array}{l}\mathrm{Pb}-\mathrm{Sn} \\
\text { " } \\
\text { " } \\
\text { " }\end{array}$ & $\begin{array}{l}\alpha-611 \\
" \\
" \\
" \\
"\end{array}$ & $\begin{array}{l}1550 \\
1050 \\
1060 \\
1110 \\
1060\end{array}$ & $\begin{array}{l}1375 \\
- \\
1600 \\
1275 \\
1200\end{array}$ \\
\hline $\begin{array}{r}3 \\
4 \\
5 \\
17 \\
18 \\
19 \\
20\end{array}$ & $\begin{array}{l}\text { Sn } \\
\text { ii" } \\
" 1 \\
" \\
" \\
"\end{array}$ & $\begin{array}{l}\text { Sn } \\
\text { " } \\
" \\
" \\
" \\
\text { " }\end{array}$ & $\begin{array}{l}\text { organic } \\
\text { " } \\
\text { " } \\
\text { " } \\
\text { " }\end{array}$ & $\begin{array}{l}1150 * \\
750 * \\
850 * \\
980 \\
1130 \\
960 \\
1030\end{array}$ & $\begin{array}{l}- \\
- \\
- \\
1100 \\
1250 \\
1180 \\
425\end{array}$ \\
\hline $\begin{array}{l}6 \\
32 \\
33 \\
34 \\
35 \\
36 \\
37\end{array}$ & $\begin{array}{l}\text { Sn-.12n } \\
\text { " } \\
\text { " } \\
\text { " } \\
\text { " }\end{array}$ & $\begin{array}{l}\mathrm{Pb}-\mathrm{Sn} \\
" \\
" \\
" \\
" \\
" \\
"\end{array}$ & $\begin{array}{l}a-611 \\
" \\
" \\
" \\
" \\
" \\
"\end{array}$ & $\begin{array}{r}1040 \\
1110 \\
1030 \\
1100 \\
960 \\
1050 \\
1140\end{array}$ & $\begin{array}{r}1025 \\
675 \\
775 \\
775 \\
700 \\
800 \\
700\end{array}$ \\
\hline $\begin{array}{r}8 \\
9 \\
10 \\
27 \\
28 \\
29\end{array}$ & $\begin{array}{l}\text { SN-.12n } \\
\text { " } \\
\text { " } \\
" \\
\text { " }\end{array}$ & $\begin{array}{l}\mathrm{Pb}-\mathrm{Sn} \\
" \\
" \\
" \\
" \\
"\end{array}$ & $\begin{array}{l}\text { organic } \\
\text { " } \\
\text { " } \\
\text { " } \\
\text { " }\end{array}$ & $\begin{array}{r}800 \\
1220 \\
1000 \\
1040 \\
925 \\
960\end{array}$ & $\begin{array}{l}- \\
1100 \\
\overline{1} \\
800 \\
800 \\
1050\end{array}$ \\
\hline
\end{tabular}

*failure by cell breakage. 


\subsection{Module Assembly}

\subsubsection{Bonding and Back Coating Materials}

The current status of candidate materials which have been considered for cell to superstrate bonding and for module back coating is reviewed in Tables $3-17$ and 3-18 respectively.

Testing of candidate adhesive materials was continued and Table 3-19 reviews the bond strength-environmental exposure tests made to date. The greatly reduced strength of glass to glass relative to cell to cell bonds with the RTV-615/4120 primer system after humidity exposure appears to be anomalous and will be further investigated. 
Table 3-17

Status of Cand date Adhesive Materials

Manufacturer

Identification

Type

Comments

\section{Retained for further consideration}

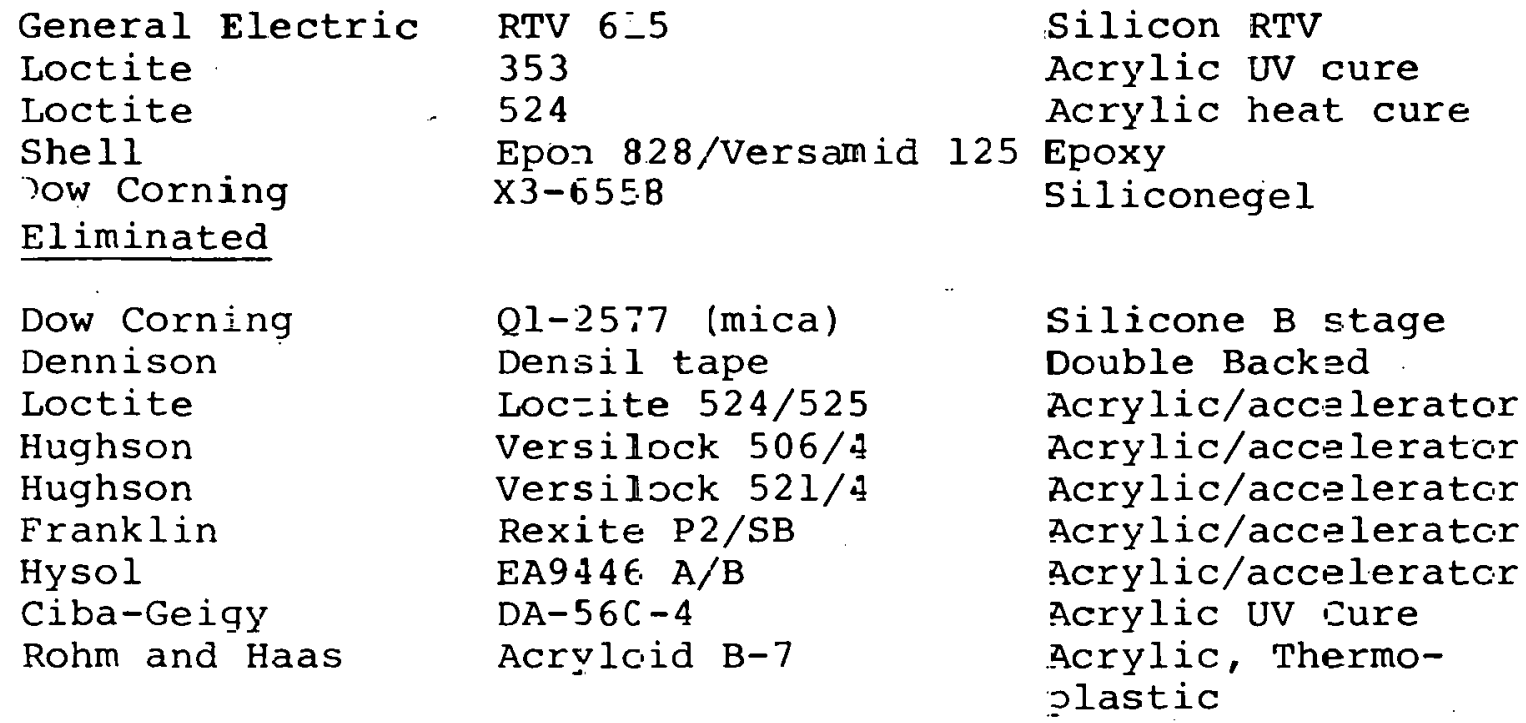

Poor adhesion and permanently soft, tacky surface

Poor light transmission

Bubbles and unbonded areas

Poor light transmission

Poor light transmission

Poor light transmission

Poor light transmission

Poor light transmission

Poor temperature resistance

Bubbles and unbonded areas, poor temperature resistance 
Status of Candidate Protective Coating Materials

\begin{tabular}{|c|c|c|c|}
\hline Manufacturer & $\begin{array}{r}\text { Identification } \\
\text { Ret }\end{array}$ & $\begin{array}{l}\text { Type } \\
\text { for Further Considerat }\end{array}$ & $\begin{array}{l}\text { Comments } \\
\text { ion }\end{array}$ \\
\hline $\begin{array}{l}\text { Dow Corning } \\
\text { Dow Corning } \\
\text { Dow Corning } \\
\text { Contour Chem. Co. } \\
\text { Product Techniques } \\
\text { Photo Chem Prod. } \\
\text { Bostic Finch } \\
\text { Deft Chem. Coat. } \\
\text { Rustoleum }\end{array}$ & $\begin{array}{l}\text { Q1-2577 } \\
\text { R-4-3117 } \\
\text { X3-5035 } \\
\text { XB-1786 } \\
\text { PT } 469 \text { Clear } \\
\text { Perma Resin } \\
\text { MIL-C-83286 } \\
\text { MIL-L-81352 } \\
\text { C-1590 white }\end{array}$ & $\begin{array}{l}\text { Silicone Coating } \\
\text { Silicone Coating } \\
\text { Silicone Emulsion } \\
\text { Silicone Coating } \\
\text { Modified Acrylic } \\
\text { Epoxy-Acrylic } \\
\text { Polyurethane } \\
\text { Acrylic } \\
\text { Alkyd }\end{array}$ & \\
\hline \multicolumn{4}{|c|}{ Eliminated } \\
\hline $\begin{array}{l}\text { General Electric } \\
\text { Rohm \& Haas } \\
\text { Mobay }\end{array}$ & $\begin{array}{l}\text { RTV } 615 \\
\text { QR-568; } \\
\text { Desmodure N75 } \\
\text { (3-6553 }\end{array}$ & $\begin{array}{l}\text { Silicone } \\
\text { Dxazolidine Acrylic/ } \\
\text { Polyurethane }\end{array}$ & $\begin{array}{l}\text { Poor adhesion } \\
\text { Delamination during } \\
\text { thermal cycle }\end{array}$ \\
\hline Rohm \& Haas & Acryloid B-7 & Acrylic & $\begin{array}{l}\text { tacky surface } \\
\text { Poor adhesion }\end{array}$ \\
\hline
\end{tabular}


Table 3-19

\section{MATERIAL}

\section{RTV615}

RTV615/4120 Prim

RTV615/4155 Prim $\mathrm{X} 3-6558$

Loctite 524

Epon 828/Vers 125

$\underset{⿱}{1}$
BOND STRENGTH/EXPOSURE

LAP SHEAR STRENGTHS LBS/IN ${ }^{2}$

(F.VERAGE APPROX. 10 SPECIMENS)

AFTER

THERMAL CYCLE

AS BONDED $\quad-40^{\circ}$ to $100^{\circ} \mathrm{C}$

CELI GLASS

$145 \quad 173$

$330 \quad 250$

CELL

GLASS

$\begin{array}{rl}86 & 191 \\ 195 & 238 \\ & 234 \\ 8.5 & 125 \\ 566 & 428 \\ 272 & 273 \\ 102 & 597\end{array}$

AFTER

HUMIDITY $95 \%$ a $70^{\circ} \mathrm{C}$

CELL GLASS

$\begin{array}{rr}250 & 218 \\ 310 & 95 \\ & 266 \\ 12.3 & 161 \\ 368 & 280 \\ 436 & 278 \\ 468 & 453\end{array}$




\subsubsection{Glass Evaluation}

A 16 cell laminated module has been adapted for evaluation of light transmission properties. The material to be tested is placed on the glass face plate of the laminated module. Cyclohexane (index of refraction $=1.42662$ ) is used as an optical coupling agent to minimize reflections at the interface between the test material and the glass module face. The current-voltage curve is measured in a solar simulator with and without the test specimen in position. The combined effect of test material absorption and difference in the reflection between the test material and glass module surface can be inferred from the observed short circuit current.

Samples of double strength ( 0.125 inch) low iron content sheet glass (LO-IRON) and water clear (SUNADEX) glass obtained from ASG Industries Inc. were tested in this equipment. These glasses are specified by the manufacturer to have nominal iron contents of $0.05 \%$ and $0.01 \%$ respectively. Observed values of short circuit current and current at a test voltage of 7.2 volts are reported in Table 3-20. Since in this case the test samples are glass, the difference in reflection will be zero to a first approximation. The observed effects are therefore all attributable to absorption. Although not measured in this experiment, we have observed that ordinary float glass (iron content 0.128 ) causes a reduction in output of the test module of 6 to 12 percent. 
Table 3-19

Transmission Measurements of 1/8" thick SUNADEX glass and LO-IRON sheet glass using 16 cell solar circuit test panels.

$\begin{array}{lrrlccc}\text { Sample } & \begin{array}{c}I_{\text {SC }} \\ (\mathrm{mA})\end{array} & \begin{array}{c}\mathrm{I}_{7.2} \\ (\mathrm{~mA})\end{array} & \begin{array}{l}\mathrm{V}_{\text {OC }} \\ (\mathrm{V})\end{array} & \begin{array}{c}\mathrm{I}_{\text {SC }} \\ (\mathrm{mA})\end{array} & \begin{array}{c}I_{7.2} \\ (\mathrm{~mA})\end{array} & \begin{array}{c}V_{\text {OC }} \\ (\mathrm{V})\end{array} \\ \text { Test Panel } & 649 & 580 & 9.32 & - & - & - \\ \text { LO IRON } & 627 & 565 & 9.31 & -3.39 & -2.58 & -0.11 \\ \text { SUINADEX } & 642 & 577 & 9.30 & -1.08 & -0.52 & =0.21\end{array}$

We have received quotes for large quantities of SUNADEX and LO-IRON and float glass from ASG Industries which are given in Table 3-19. Using this cost data and the transmission data from Table 3-18 one can estimate the relative cost effectiveness of these two glasses. Assuming. a module efficiency of $12 \%$ with the use of LO-IRON glass, the 28 increase in output (at load) with SUNADEX glass would result in module power increasing from 11.15 watts per square foot to 11.37 watts per square foot. The increase of 0.22 watts would cost $\$ 1.09$ per watt $(\$ 0.69-0.45) \div 0.22)$. Thus under the assumed conditions, use of SUNADEX glass would be cost effective only if the base line module cost exceeds $\$ 1.09$ per watt.

\section{4:3 Module Design}

The proposed module design and selected process sequence are shown in Table $2-j$. The module design was comprised of a 24 by 48 inch $(60 \times 120 \mathrm{~cm})$ tempered glass superstrate. Square shaped cells were to be used in order to achieve $12 \%$ module efficiency goal. During the present quarter, square cells cut from 3 inch diameter Czochralski crystals have been decided on 
Glass prices for large quantity purchases of standard sizes furnished in standard cases. Minimum of 20 cases of one type of glass. Source: ASG Industries, Ringsport, Tennessee.

$\begin{array}{ccccc}\begin{array}{c}\text { Thickness } \\ \text { inch }\end{array} & \begin{array}{c}\text { Std. Size } \\ \text { inch }\end{array} & \text { SUNADEX } & \begin{array}{c}\text { Price } \$ \text { per sq. } \\ \text { LRON } \\ \text { sheet }\end{array} & \begin{array}{c}\text { ft. } \\ \text { STARLUX } \\ \text { float }\end{array} \\ 1 / 8 & 34 \times 76 & .69 & .45 & .47 \\ 5 / 32 & 34 \times 76 & .80 & .53 & \text { NA } \\ & 34 \times 84 & \text { NA } & .53 & \text { NA } \\ & 34 \times 96 & .80 & \text { NA } & \text { NA } \\ 3 / 16 & 34 \times 76 & \text { NA } & .61 & .51 \\ & 34 \times 96 & .91 & \text { NA } & \text { NA } \\ & 46 \times 76 & .91 & .61 & .51 \\ & 46 \times 84 & \text { NA } & .61 & .51 \\ 7 / 16 & 46 \times 92 & \text { NA } & \text { NA } & .51 \\ & 46 \times 96 & .91 & \text { NA } & \text { NA } \\ & 46 \times 96 & 1.03 & \text { NA } & \text { NA }\end{array}$

\begin{tabular}{|c|c|c|c|c|c|}
\hline \multirow[b]{3}{*}{$\star 1 / 8$} & \multirow{2}{*}{\multicolumn{2}{|c|}{ SUNADEX }} & Case & Weight & \& Footage \\
\hline & & & LOW & IRON & STARLUX \\
\hline & $2000 \#$ & $1200^{\circ}$ & 2000\# & $1200^{\circ}$ & $3000 \# 1200^{\prime}$ \\
\hline $5 / 32$ & $2000 \#$ & $1000^{\circ}$ & $2000 \#$ & $1000^{\circ}$ & NA \\
\hline $3 / 16$ & $2000 \#$ & $900^{\prime}$ & $2000 \#$ & $900^{\circ}$ & $270081000^{\circ}$ \\
\hline $7 / 16$ & $2000 \#$ & $700^{\prime}$ & $\mathbf{N}$ & A & NA \\
\hline
\end{tabular}

*Shipping cost .12 per sq. ft. 
as test vehicles for process verification in anticipation of larger square or rectangular sheet materials becoming available. The crystals will be shaped into prisms with square cross section prior to sawing wafers. The nominal wafer dimension will be $5.38 \mathrm{~cm}(2.12$ inches) on the side. A tentative module design (Figure 9) has been prepared comprised of a 10 × 20 cell layout. Cells will be interconnected into a circuit with ten cells in parallel and twenty cells in series. Figure 10 shows the superstrate design for this circuit. This design could be easily modified into a circuit with five cells in parallel and forty cells in series. These circuits are expected to have a peak power of 84 watts at $28^{\circ} \mathrm{C}$ and either 9.4 or 18.8 volts respectively. This is based on an assumed $15 \%$ cell efficiency. The corresponding module efficiency is

$$
\frac{2.12^{2} \times 200(\text { cell area })}{16.03 \times 23.35 \text { (module area) }} \times 15 \%=12.5 \%
$$




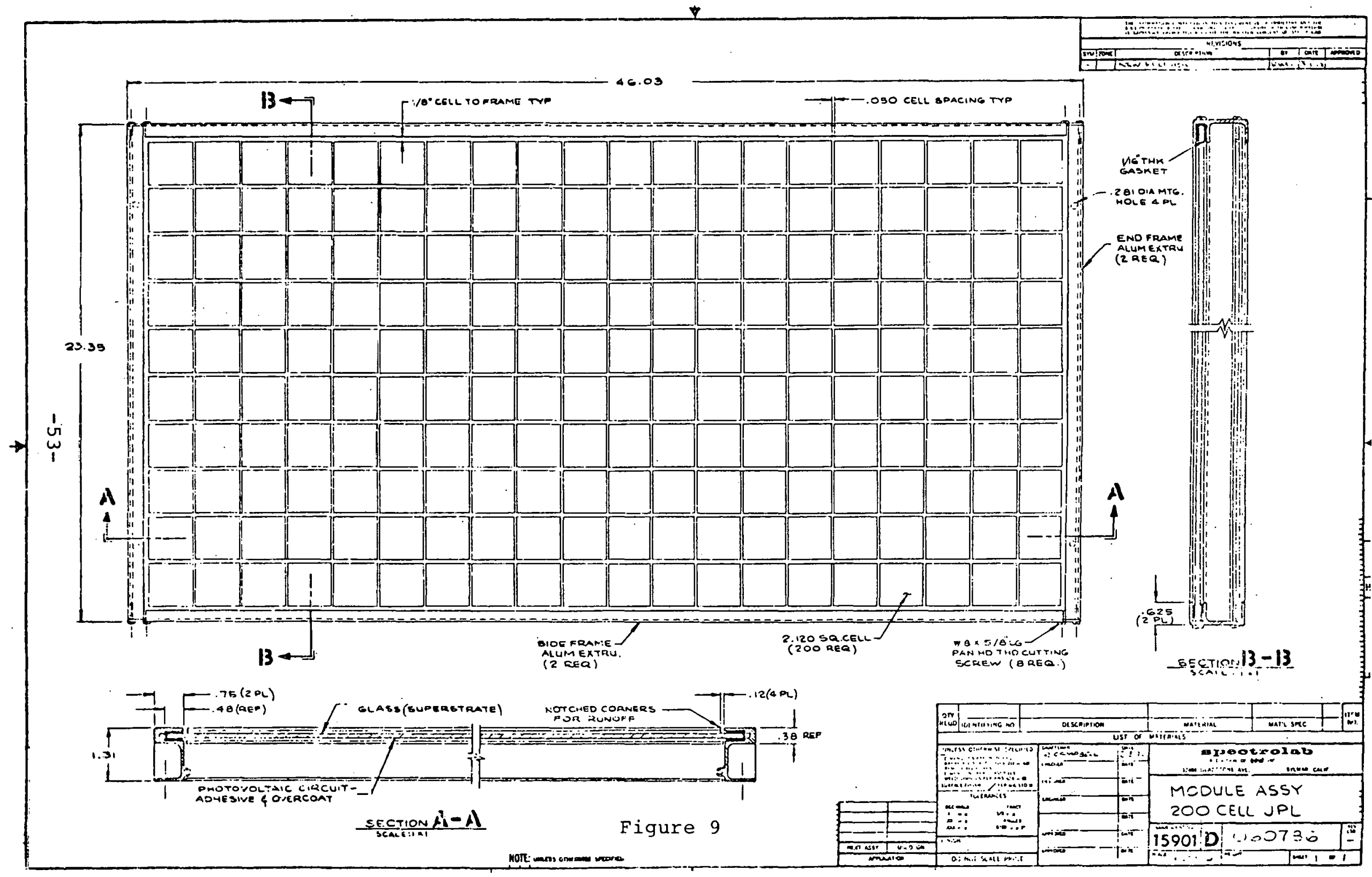




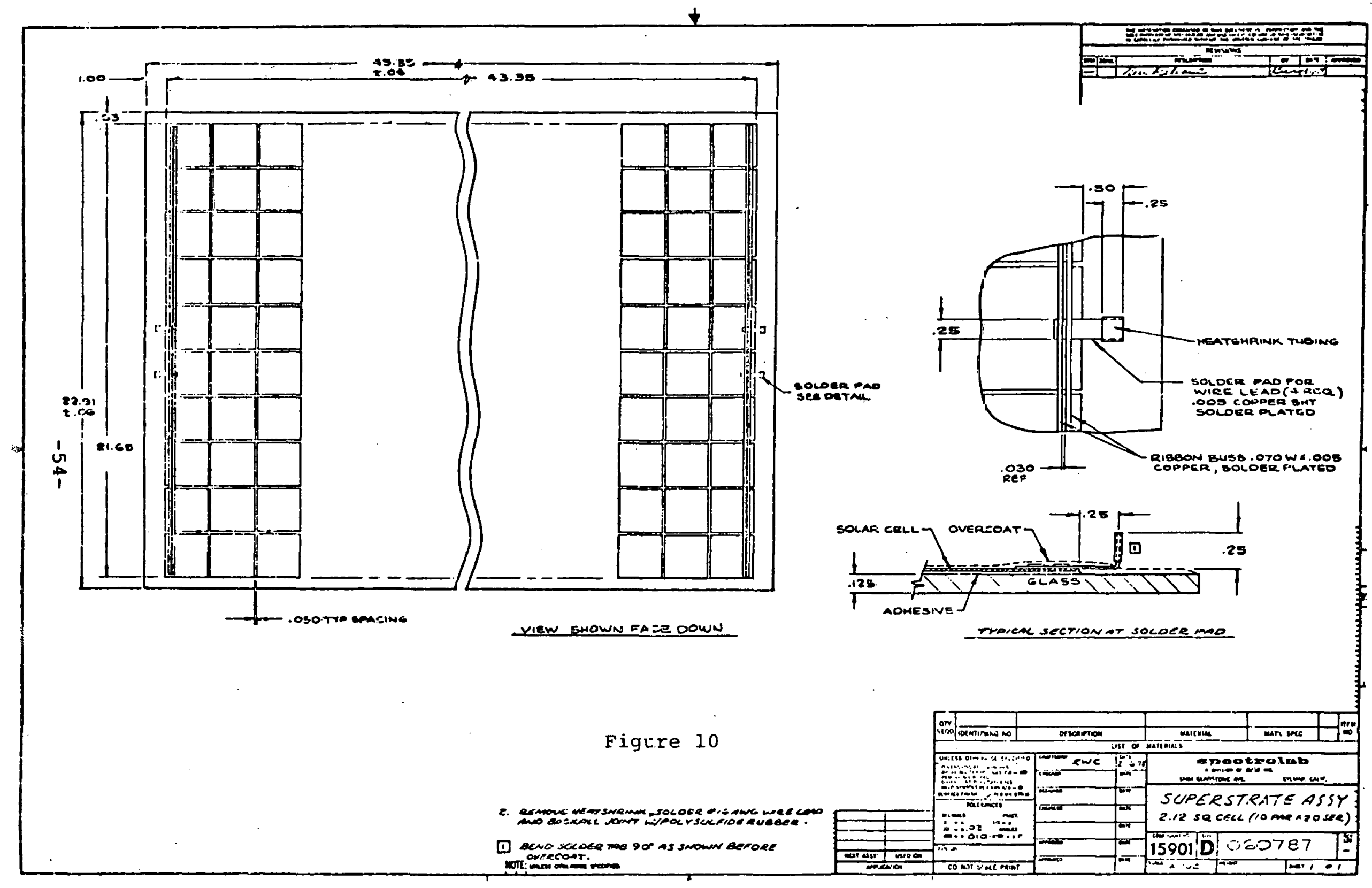




\subsection{CONCLUS IONS}

The following conclusions have been drawn on the basis of the work reported here:

a. Differences in cell output are not relatable to observed differences in the surface topography of individual cells within cell lots subjected to a given texture etch surface treatment.

b. Prolonged pre-etch to remove surface damage induces the formation of thin pyramids during the texture"etch which may be associated with a higher incidence of low output cells as a consequence of greater pyramid fragility.

c. Magnesia-aluminia-borosilicate glass are not satisfactory for consideration as diffusion masking dielectrics because of excessive refractoryness.

d. Titania precipitated glass has properties, (refractoryness, contact angle, expansion coefficient, adhesion and maturation temperature) suitable for processing as a diffusion dielectric and has diffusion barrier behaviour in preliminary tests with Emulsitone $W-250$ phoshorous diffusion source. However, problems have been encountered in incorporating the process into the cell processing sequence.

e. Emulsitone $W-250$ is a suitable phosphorous diffusion source for the fabrication of solar cells.

f. Several commercial fritted silver screen printing pastes are suitable candidates for front contact metallization. Commercial pastes can sometimes be improved by adjusting the frit content and/or by adding donar sources.

g. Printed silver solder pads are unsuitable on aluminum back contacts due to their susceptibility to corrosive attach by water vapor. 
h. Tin solder pads on aluminum back contacts are resistant to corrosive attack.

i. Low iron sheet glass is more cost effective than water clear (SUNADEX) glass for use as a module superstrate if module cost is less than $\$ 1.09$ per watt according to current large volume price quotations. 


\subsection{RECOMMENDATIONS}

There are no recommendations.

\subsection{NEW TECHNOLOGY}

There was no new technology reported during the quarter. 


\subsection{REFERENCES}

1. W.E. Taylor, Array Automated Assembly, Phase 2, (Sylmar, California: Spectrolab, Inc.) JPL Contract 954853, Quarterly Report (Fèbruary, 1978), DOE/JPL954853-78/1

2. J.W. Thornhill, Automated Fabrication of Back Surface Field S1licon Snlar relis with Screen Printed Wraparound contacts; (Sylmar, California, Spectrolab, Inc.), NASA/LRC Contract NAS3-20029, Final Report, (August, 1977), NASA CR-135202, 